\title{
A Primer on Citizenship Revocation for WWII Collaboration: The 1998-1999 Federal Court Term
}

\author{
Claire I. Farid
}

This article provides a review of recent jurisprudence in relation to revocation of citizenship proceedings against those alleged to have committed war crimes or crimes against humanity. The author discusses proceedings involving citizenship obtained by deception by those involved in World War $I I$, with a particular focus on five cases decided in late 1998 and 1999.

The article addresses both procedural and substantive issues that have arisen in these proceedings. Although past procedural problems of characterization of the proceedings, the scope of required notices, and rights to appeal have generally been clarified in recent jurisprudence, some specific problems still remain to be resolved. The author points out that the substantive issues surrounding collaboration, actual post-WWII security screening practices, the existence of a duty of candour, and the legal authority for security screening of immigration applicants still remain in a state of uncertainty as the current cases have provided conflicting results. Interpretation of old legislation and the determination of how such legislation was actually applied to security screening by immigration officials at the time of the immigrant's application are the main concerns in deciding these substantive issues. Matters are further complicated by the lack of evidence, both testimonial and documentary. The resolution, or lack thereof, of the procedural and substantive issues will have $a$ bearing on proceedings initiated by the government in relation to modern war crimes cases.
Cet article récapitule la récente juridiction en matière de procès de révocation de citoyenneté contre les présumés criminels de guerre ou de crimes contre l'humanité. L'auteur discute des procédures relatives à la citoyenneté obtenue frauduleusement par ceux qui ont pris part $\dot{a}$ la Seconde Guerre mondiale; il se penche particulièrement sur cinq causes jugées vers la fin de 1998 et 1999.

L'article porte autant sur les questions de procédure que de fond qui sont apparues au cours des procès. Bien que par le passé, les questions de caractérisation des procédures, la portée des avis requis et les droits d'appel aient généralement été clarifiées dans la dernière jurisprudence, certaines questions spécifiques demeurent. L'auteur fait remarquer que les questions de fond concernant la collaboration, les pratiques de sécurité en vigueur après la Seconde Guerre mondiale, l'existence d'une obligation de franchise et l'autorité légale d'effectuer un triage sécuritaire des candidats à l'immigration demeurent encore incertaines étant donné que les causes actuelles ont donné des résultats conflictuels. L'interprétation d'anciennes lois et la détermination de savoir de quelles façons les responsables de l'immigration appliquaient ces lois lors de l'évaluation de sécurité des candidats à l'immigration sont au caur de ces questions de fond. Les questions se compliquent davantage par un manque de preuve, autant sous forme de témoignages que de documents. La résolution, ou l'absence de résolution, des questions de procédure et de fond auront une incidence sur les poursuites engagées par le gouvernement dans le cas des causes concernant les crimes de guerre modernes.

\section{TABLE OF CONTENTS}

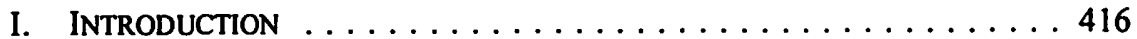

II. THE STATUTORY FRAMEWORK FOR

CITIZENSHIP REVOCATION ...................4 417

III. Citizenship Revocation Proceedings . . . . . . . . . . 421

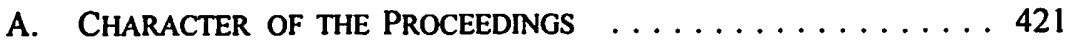

B. THE NOTICE OF REVOCATION ... . . . . . . . . . . . 424

C. APPEALS .......................... . 429

Former clerk at the Federal Court of Appeal, currently practicing law in Ottawa, Ontario. This article soley represents the views of the author. 
IV. SUBSTANTIVE ISSUES IN WWII REVOCATION CASES:

CANADA'S IMMigRaTION aNd CITIZENSHIP LAW, POLICY, and Practice Post-WWII $\ldots \ldots \ldots \ldots \ldots \ldots \ldots \ldots \ldots 33$

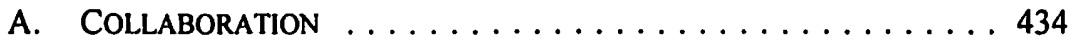

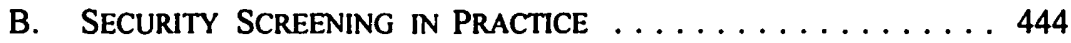

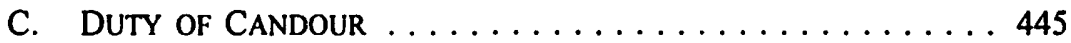

D. LEGAL AUTHORITY FOR SECURITY SCREENING ... . . . . . 449

V. CONCLUSION ...................... 457

\section{INTRODUCTION}

While currently Canadians witness war crimes and crimes against humanity occurring in Europe, Africa, and other parts of the world, hoping that those responsible can and will be punished, the Canadian Government is still struggling to bring to justice those who committed atrocities during the World War II era. As the Government has had little success in bringing criminal prosecutions against alleged WWII collaborators, ' its recent focus has been on revocation of citizenship and deportation. As of March 31, 1999, the Government was actively investigating 91 individuals in respect of WWII activities and a further eight cases were the subject of proceedings in the Federal Court of Canada. ${ }^{2}$ Between September 1998 and 1999, the Federal Court of Canada decided five such cases: Canada (Minister of Citizenship and Immigration) v. Dueck, ${ }^{3}$ Canada (Minister of Citizenship and Immigration) v. Kisluk, ${ }^{4}$ Canada (Minister of Citizenship and Immigration) v. Vitols, ${ }^{5}$ Canada (Minister of Citizenship and Immigration) v. Katriuk, ${ }^{6}$ and Canada (Minister of Citizenship and Immigration) v. Podins, ${ }^{7}$ in which the Minister of Citizenship and Immigration sought an order that alleged WWII collaborators had been admitted to Canada or obtained Canadian citizenship by way of deception about their involvement in assisting the Germans in the WWII era. A positive finding in this respect would be the first step in the process leading to revocation of citizenship and possible deportation of the individuals involved.

The notion of "collaboration" will be discussed in detail below. While criminal prosecutions were commenced in four cases between 1987 and 1992, none were successful. In $R$ v. Finta, [1994] 1 S.C.R. 701 [hereinafter Finta], the Supreme Court of Canada upheld the acquittal. According to the Department of Justice,

The decision of the Supreme Court in 1994 to uphold the acquittal [of Imre Finta], and the reasons given by the Court, made it impractical to proceed with further cases under the existing provisions of the Criminal Code.

Department of Justice Canada, Public Report, Canada's War Crimes Program: 1998-1999 (Ottawa: July 27, 1999) at 2 (hereinafter 1998-1999 Annual Report]. For a further discussion of Finta, see I. Colter, "War Crimes Law and the Finta Case" (1995) 6 Supreme Court L.R. (2d) 577 and D. Matas, "The Case of Imre Finta" (1994) 43 U.N.B.L.J. 281.

It is of note that on December 10, 1999, the Government introduced new legislation dealing with war crimes and crimes against humanity, Bill C-19, An Act respecting genocide, crimes against humanity and war crimes and to implement the Rome Statute of the International Criminal Code, and to make consequential amendments to other Acts, 2d Sess., 36th Parl., 1999. 1998-1999 Annual Report, ibid. at 18.

(1998), 155 F.T.R. 1 (T.D.), Noël J. [hereinafter Dueck].

[1999] F.C.J. No. 824 (T.D.), Lufty J., online: (QL) (FCJ) [hereinafter Kisluk].

(1998), 151 F.T.R. 161 (T.D.), McKeown J. [hereinafter Vitols].

[1999] F.C.J. No. 90 (T.D.), Nadon J., online: (QL) (FCJ) [hereinafter Katriuk].

[1999] F.C.J. No. 1092 (T.D.), McKeown J., online: QL (FCJ) [hereinafter Podins]. 
Although the first case of this nature, Canada (Secretary of State) v. Luitjens ${ }^{8}$ was decided in 1991, the release this year of five such cases provides an excellent opportunity to review and evaluate the emerging jurisprudence. This article will present a broad overview of the area and some of the important issues that have recently arisen. After first discussing the statutory framework for citizenship revocation, a number of important procedural issues in revocation cases, such as the availability of appeals, will be examined. Then, with particular focus on the cases decided in 1999, the discussion will turn to a more in-depth examination of a number of substantive issues to be decided in a citizenship revocation case. These issues all relate to proof of the alleged deception and include whether after WWII Canada sought to exclude collaborators, Canada was consistently attempting to screen such immigrants out, immigrants had a duty to disclose their wartime history absent questions, and, finally, in the immediate post-WWII period whether there was legal authority to security screen potential immigrants to Canada.

These are by no means easy cases to litigate as the evidence is some 50 years old. Aging evidence is clearly a great obstacle to the Government's success in citizenship revocation for cases involving WWII collaboration. In 1999, the Government was successful only in two of the five cases decided by the Federal Court. As this article will demonstrate, although the burden on the Minister is much lower than that in the criminal context, in respect of WWI collaboration, citizenship revocation proceedings are nonetheless extremely complex and present an uphill battle for the Government.

\section{The Statutory Framework for Citizenship Revocation}

The scheme for citizenship revocation is found in the current Citizenship Act ${ }^{9}$ which provides that no one will cease to be a citizen except as provided by Part II of the Act. ${ }^{10}$ Section 10 of the $A c t$, found in Part II, sets out the substantive basis upon which an individual may lose citizenship:

10. (1) Subject to section 18 but notwithstanding any other section of this Act, where the Governorin-Council, on a report from the Minister, is satisfied that any person has obtained, retained, renounced or resumed citizenship under this Act by false representation or fraud or by knowingly concealing material circumstances,

(a) the person ceases to be a citizen, or

(b) the renunciation of citizenship by the person shall be deemed to have had no effect,

as of such date as may be fixed by order of the Governor-in-Council with respect thereto.

(2) A person shall be deemed to have obtained citizenship by false representation or fraud or by knowingly concealing material circumstances if the person was lawfully admitted to Canada for

(1991), 46 F.T.R. 267 (T.D.) [hereinafter Luitjens].

R.S.C. 1985 , c. C-29 [hereinafter $A c t$ ].

lbid. at $\mathbf{s .} 7$. 
permanent residence by false representation or fraud or by knowingly concealing material circumstances and, because of that admission, the person subsequently obtained citizenship."

Thus, it is the Governor-in-Council which ultimately revokes citizenship, based on a report from the Minister of Citizenship and Immigration that the individual concerned has through some form of deception ${ }^{12}$ obtained Canadian citizenship. Section $10(2)$ is a deeming provision which specifies that, where an individual obtained permanent residence through deception and subsequently obtained citizenship, his or her citizenship is considered to have been obtained through deception.

Section 18 then sets out the procedure under which this revocation is to occur:

(1) The Minister shall not make a report under section 10 unless the Minister has given notice of his intention to do so to the person in respect of whom the report is to be made and

(a) that person does not, within thirty days after the day on which the notice is sent, request that the Minister refer the case to the Court; or

(b) that person does so request and the Court decides that the person has obtained, retained, renounced or resumed citizenship by false representation or fraud or by knowingly concealing material circumstances.

(2) The notice referred to in subsection (1) shall state that the person in respect of whom the report is to be made may, within thirty days after the day on which the notice is sent to him, request that the Minister refer the case to the Court, and such notice is sufficient if it is sent by registered mail to the person at his latest known address.

(3) A decision of the Court made under subsection (1) is final and, notwithstanding any other Act of Parliament, no appeal lies therefrom.'

"Ibid. at s. 10. The French version of this provision reads:

10. (1) Sous réserve du seul article 18, le gouverneur en conseil peut, lorsqu'il est convaincu, sur rapport du ministre, que l'acquisition, la conservation ou la répudiation de la citoyenneté, ou la réintégration dans celle-ci, est intervenue sous le régime de la présente loi par fraude ou au moyen d'une fausse déclaration ou de la dissimulation intentionnelle de faits essentiels, prendre un décret aux termes duquel l'intéressé, à compter de la date qui y est fixé:

a) soit perd sa citoyenneté;

b) soit est réputé ne pas avoir répudié sa citoyenneté.

(2) Est réputée avoir acquis la citoyenneté par fraude, fausse déclaration ou dissimulation intentionnelle de faits essentiels la personne qui l'a acquise à raison d'une admission légale au Canada à titre de résident permanent obtenue par l'un de ces trois moyens.

12 I use the term "deception" to capture false representation, fraud, or knowing concealment of material circumstances.

1. Act, supra note 9 at $\mathrm{s}$. 18. The French version of this provision reads:

18. (1) Le ministre ne peut procéder à l'établissement du rapport mentionné à l'article 10 sans avoir auparavant avisé l'inté ressé de son intention en ce sens et sans que l'une ou l'autre des conditions suivantes ne se soit réalisée:

a) l'intéressé n'a pas, dans les trente jours suivant la date d'expédition de l'avis, demandé le renvoi de l'affaire devant la Cour; 
Thus, the Minister may not submit a report to the Governor-in-Council until (1) she has given notice to the individual in respect of whom the report is to be made and (2), after the elapse of thirty days, the individual has not made a request to the Minister that the case be referred to the Federal Court - Trial Division (the "Court"), ${ }^{14}$ or, if the individual does make a request for a reference, after the Court makes a positive finding ${ }^{15}$ in respect of the case referred to it.

Sections 10 and 18 thus contemplate very different roles for the Governor-in-Council, the Minister, and the Court in the citizenship revocation process. As has been decided by the Federal Court of Appeal in Canada (Secretary of State) v. Luitjens, ${ }^{16}$ the Court is simply a fact-finder with respect to whether the individual obtained his or her citizenship by means of deception. According to this analysis, the factual decision does not finally determine any legal rights and, as stated by Linden J.A. for the Court of Appeal:

This finding may well form the basis of decisions by others, which may interfere with those rights at some future time, but this decision does not do so. ${ }^{17}$

This statement by Linden J.A. also implies that a positive factual determination by the Court may not lead to citizenship revocation. The wording of $\mathrm{s}$. 18 is consistent with this analysis and, while providing that the Minister shall not make a report to the Governor-in-Council unless the requirements of s. 18(1) have been met, does not make such a report mandatory in the face of a positive finding by the Court. This appears to leave the Minister some discretion whether to make a report where the conditions of s. 18(1) have been met and, in my view, this discretion could prove important. One instance where it could be exercised is if there are multiple and cumulative allegations against an individual and the Court makes a positive finding in respect of only some of them; the Minister could decide not to make a report where in her view the proven allegations are insufficiently serious to warrant citizenship revocation.

The ultimate decision maker in respect of citizenship revocation is the Governor-inCouncil which must be "satisfied" on the Minister's report that the individual has obtained citizenship by deception. As the Governor-in-Council must be satisfied, it appears that, even upon a positive determination by the Court and a report by the

b) la Cour, saisie de l'affaire, a décidé qu'il y avait eu fraude, fausse déclaration ou dissimulation intentionnelle de faits essentiels.

(2) L'avis prévu au paragraphe (1) doit spécifier la faculté qu'a l'intéressé, dans les trente jours suivant sa date d'expédition, de demander au ministre le renvoi de l'affaire devant la Cour. La communication de l'avis peut se faire par courrier recommandé envoyé à la dernière adresse connue de l'intéressé.

(3) La décision de la Cour visée au paragraphe (1) est définitive et, par dérogation à toute autre loi fédérale, non susceptible d'appel.

14 Section 2(1) of the Act, ibid, defines "Court" as the Federal Court - Trial Division.

is References in this article to a positive finding by the Court indicate a finding by the Court that the allegations against the respondent have in fact been proven; the individual has been found by the Court to have obtained citizenship by deception.

16 (1992), 142 N.R. 173 (F.C.A.) [hereinafter Luitjens No. 2].

17 Ibid. at 175 [emphasis in original]. 
Minister, revocation is not a foregone conclusion. It is difficult to contemplate the circumstances in which the Governor-in-Council would not in fact be satisfied in the face of a positive determination by the Court; ${ }^{18}$ the wording of s. $10(1)$, nevertheless, appears to leave open this possibility.

Once the Governor-in-Council is satisfied in this respect, there is an "automatic statutory cessation of citizenship." ${ }^{19}$ As stated by McGillis J. in Copeland:

In the event that a statutory cessation of citizenship takes effect under subsection 10(1) of the Citizenship Act, the person would become a permanent resident in Canada, as that term is defined in subsection 2(1) [as am. by S.C. 1992, c. 49 s. 1] of the Immigration Act, R.S.C., 1985, c. 1-2, as amended. As a result, the person would be subject to all of the provisions of the Immigration Act, including those pertaining to removal from Canada. ${ }^{20}$

In contrast, where citizenship is revoked on the basis of the s. 10(2) deeming provision, the individual does not become a permanent resident and would appear to be without status under the Immigration Act. $^{21}$

Changes proposed in Bill C-63, the Citizenship of Canada Act, ${ }^{22}$ would have made substantial amendments to the $A c t$ as it now reads. Citizenship could have been revoked for "false representation or fraud or by concealing material circumstances" on an application for citizenship or permanent residence; "knowing" concealment of material circumstances would no longer have been required for revocation. ${ }^{23}$ Further, it would have been possible to revoke the citizenship not only of the individual who had gained it through deception, but also the citizenship of individuals who acquired it through this person, thus including children. ${ }^{24}$ In Committee, both these changes were criticized and eliminated and Bill C-63 subsequently died on the order paper. On November 25, 1999, the Government re-introduced a new Citizenship of Canada Act, Bill C-16; this bill incorporates the above changes proposed in Committee. ${ }^{25}$ As a result, the basic provisions respecting revocation would remain unchanged.

It appears that the Governor-in-Council must only be satisfied of the fact that the individual gained citizenship by deception.

19 Canada (Minister of Citizenship and Immigration) v. Copeland (1997), [1998] 2 F.C. 493 at 506 (T.D.) [hereinafter Copeland].

21 Ibid. See also Canada (Minister of Citizenship and Immigration ) v. Bogutin (1998), 144 F.T.R. 1 at 30 (T.D.) [hereinafter Bogutin] for a statement to the same effect.

21 The definition of "permanent resident" in the Immigration Act, R.S.C. 1985, c. I-2, as am. by S.C. 1992, c. 49 [hereinafter Immigration Act, 1985], includes:

...a person who has become a Canadian citizen but who has subsequently ceased to be a Canadian citizen under subsection $10(1)$ of the Citizenship Act, without reference to subsection 10(2) of that Act.

See also Canada (Minister of Citizenship and Immigration) v. Singh (1996), 117 F.T.R. 297 (T.D.). Ist Sess., 36th Parl., 1997-98 (1st reading 7 December 1998).

Ibid. at ss. 16(1), 16(3).

Ibid. at s. 16(4).

Library of Parliament, Bill C-63: The Citizenship of Canada Act (Legislative Summary) by M. Young (Ottawa: Library of Parliament, 1999) at 7; Bill C-16, Citizenship of Canada Act, 2d Sess., 36th Parl., 1999 (1st reading 25 November 1999) [hereinafter Bill C-16]. 
A further and even more substantial change to the Act found in Bill C-16 would allow the Minister to annul an individual's citizenship if it was obtained within the previous five years using a false identity or if the individual falls within a number of enumerated classes. ${ }^{26}$ One class affected by these provisions is those who are under investigation, subject to proceedings, or convicted in relation to offences under $\mathbf{s}$. 7(3.71) of the Criminal Code; these are the provisions relating to war crimes and crimes against humanity. ${ }^{27}$ The legal effect of such a ministerial order would be that the individual never obtained citizenship, nor would anyone who gained citizenship through him or her. This decision by the Minister could only be challenged by way of judicial review. ${ }^{28}$ These new provisions would provide the Minister with a powerful new tool to expel war criminals from Canada.

\section{Citizenship Revocation Proceedings}

Although the current legislative framework for citizenship revocation has been in place for some twenty years, until recently, it is not a measure that has been used frequently. As a result, it is only of late that the courts have had the opportunity to clarify the type of proceedings contemplated by ss. 10 and 18 and thus identify the procedural protections afforded to the individual against whom the proceedings are brought. This section will examine the nature or character of the proceedings and two important aspects of them: the effect of the Notice of Revocation and the possibility of appeals.

\section{A. Character of the Proceedings}

For some, the most conceptually difficult aspect of citizenship revocation proceedings in respect of alleged WWII collaboration is that, in legal terms, the individual is not on trial for his or her alleged participation. Rather the issue is simply and only whether the individual "obtained, retained, renounced or resumed citizenship" through deception about such participation. ${ }^{29}$ This distinction is important as it relates directly to the type of proceedings under s. 18(1) of the Act.

In addressing this issue, Collier J. in Canada (Secretary of State) v. Luitjens ${ }^{30}$ stated that:

I am satisfied the present proceeding is a civil proceeding. I had been tempted, alternatively, to use the phrase, a quasi-criminal proceeding. That, to my mind, would be too imprecise and create confusion.

Bill C-I6, ibid. at ss. 18, 28.

Ibid. at ss. $28(f), 28(\mathrm{~g})$.

Ibid. at s. 18(4).

Canada (Minister of Citizenship and Immigration) v. Tobiass, [1997] 3 S.C.R. 391 at 413 [hereinafter Tobiass].

30

(1988), [1989] 2 F.C. 125 (T.D.) [hereinafter Luitjens No. l]. 
A high degree of probability is, in my opinion, required in a case of this kind. What is at stake here is very important; the right to keep Canadian citizenship, and the serious consequences which may result if that citizenship ceases."

The Supreme Court has also clarified that what is at stake for respondents is their citizenship and not their liberty, as would be the case in a criminal proceeding; as such, the legal interest of these respondents is less than it would be in the criminal context. ${ }^{32}$ It is now well established that citizenship revocation hearings are civil in nature, and a reference to the Court under s. 18 of the Act is to be analyzed on the basis of the principles applicable to citizenship and immigration law, not criminal law. ${ }^{33}$ The factual finding of the Court under s. 18(1) "is purely and simply a citizenship matter"34 and does not have penal consequences. ${ }^{35}$ Further, neither the motivation of the Minister in bringing the application, nor the "nature of what underlies the alleged fraud" has an impact on the nature of the proceeding. ${ }^{36}$ The issue before the Court is exactly the same whether the matter underlying the alleged deception is war crimes or marital status; the gravity of the alleged crimes is relevant only in so far as it helps to establish the fraud. ${ }^{37}$

This characterization of the proceedings is also reflected in the applicable burden of proof. As stated by McKeown J. in Bogutin:

I apply the civil standard of proof on a balance of probabilities but I must scrutinize the evidence with greater care because of the serious allegations to be established by the proof that is offered."

Bill C-16 would legislate this and confirm that the Court is to make its determination on "a balance of probabilities." 39 This civil burden explains why, from the perspective of the Minister, citizenship revocation proceedings are an attractive alternative to a criminal prosecution. ${ }^{40}$

Ibid. at 134.

Tobiass, supra note 29 at 435.

See Copeland, supra note 19 at 510.

Ibid.

Canada (Minister of Citizenship and Immigration) v. Dueck, [1998] 2 F.C. 614 at 632 (T.D.) [hereinafter Dueck No. I].

Ibid. at 626.

Ibid. at 627-28.

Bogutin, supra note 20 at 29.

Bill C-16, supra note 25 at s. 17.

It would, of course, be possible for the Minister to seek a criminal prosecution and to commence citizenship revocation proceedings.

In respect of the actual steps to be followed in a revocation proceeding, some inconsistencies in the jurisprudence developed as a result of both the initial uncertainty about the nature of the proceedings and because Division E of the former Federal Court Rules, C.R.C., c. 663 (1978), governing citizenship revocation, did not provide a detailed code of the procedure to be followed. The former Rule 920 of Division E of the Federal Court Rules read:

The following provisions shall apply to the hearing of a case (section [18] of the Act);

(a) upon receipt of a request to the Minister by a person (hereafter the "person") in respect of whom the Minister intends to make a report pursuant to section [10] of the Act that the case be referred to the Court, the Minister shall, if he decides to refer the case to the Court, forward a copy of the request and of his reference to the Court to the Registry; 
Since these proceedings could eventually lead to loss of citizenship and possible deportation, a nonetheless serious result, the level of procedural protections has been a highly contested issue, and the characterization of the proceedings as civil has had an important impact on the rights of the individual against whom a proceeding is brought. Most notable is that the Courts have held that various Charter ${ }^{41}$ rights available in the criminal context are not engaged. For example, since the individual is not "charged with an offence," the procedural protections of s. 11 are inapplicable; these include the presumption of innocence, ${ }^{42}$ the right not to be compelled as a witness in proceedings against oneself, ${ }^{43}$ and the right not to be tried twice for the same offence. ${ }^{44}$ Similarly, the right against self-incrimination under ss. 7 and 11 of the Charter is also inapplicable $^{45}$ and, thus, an interesting aspect of revocation proceedings is that the respondent can be compelled to testify. Further, s. 7 does not render unconstitutional s. 18(3) of the Act which provides that a decision under s. $18(1)$ is not subject to

(b) the Minister shall, within 14 days thereafter, file in the Registry and serve on the person,

(i) the application made by that person pursuant to subsection 13(1) of the Act,

(ii) the decision of the citizenship judge thereon,

(iii) a summary of the facts and evidence on which the Minister intends to rely at the hearing of the case, and

(iv) a list containing the names and addresses of any witnesses he proposes to call at the hearing of the case, and of any documents he proposes to tender in evidence;

(c) the provisions of Rules 906, 907, 908, 909, 910, 915, 916, 917 and 919 shall, with

all necessary modifications, apply to a case.

For example, while in the proceedings against Peter Vitols examinations for discovery were not permitted, they were ordered in the case against Serge Kisluk. (Canada (Minister of Citizenship and Immigration) v. Kisluk (1998), 41 Imm. L.R. (2d) 251 (F.C.T.D.) [hereinafter Kisluk No. I]). The issue of appropriate procedural steps was resolved to some extent on a motion for directions in the trilogy of cases which were returned to the Federal Court - Trial Division for adjudication after the Supreme Court decision in Tobiass, infra note 79. On the motion for directions it was decided that the Federal Court Rules of practice were applicable and would only be modified to the extent required by the particular nature of the proceedings under s. 18 of the Act. (Dueck No. I, supra note 35; Canada (Minister of Citizenship and Immigration) v. Tobiass (1997), 139 F.T.R. 280 (T.D.) [hereinafter Tobiass No. I]; Canada (Minister of Citizenship and Immigration) v. Oberlander (1997), 155 D.L.R. (4th) 481 (F.C.T.D.) [hereinafter Oberlander].) As a result, it was held that both the respondent and applicant would file a summary of facts and evidence by reference to the rules governing pleadings, that affidavits of documents would be exchanged, and that there would be oral discoveries. For the most part, a revocation proceeding would go forward as an action. Under the new Federal Court Rules, 1998, r. 169, revocation proceedings are specifically made subject to the rules governing actions, and this has further clarified the appropriate procedural steps to be taken. Canadian Charter of Rights and Freedoms, Part I of the Constitution Act, 1982, being Schedule B to the Canada Act, 1982 (U.K.), 1982, c. 11 [hereinafter Charter].

42 Copeland, supra note 19 at 517.

43 Dueck No. I, supra note 35 at 632-34.

4 For example, it would be possible to bring a criminal proceeding against an individual as well as a proceeding for citizenship revocation.

4s Dueck No. I, supra note 35 at 629-31. See also Canada (Minister of Citizenship and Immigration) v. Malik (1997), 128 F.T.R. 309 at 314-15 (T.D.). There may, however, be a Charter violation where there is an undue delay in respect of revocation hearings, ibid. at 315 . See Copeland, supra note 19; Canada (Secretary of State) v. Charron (1988), 21 F.T.R. 117 at 121 (T.D.); Canada v. Sadiq (1990), 39 F.T.R. 200 at 205-206 (T.D.); contra Canada (Minister of Citizenship and Immigration) v. Coomar, [1998] F.C.J. No. 1679 (T.D.), online: QL (FCJ). 
appeal; this is because the proceeding does not determine legal rights but, rather, is factual in nature. ${ }^{46}$

\section{B. The Notice of Revocation}

One particularly significant development in the recent jurisprudence has been the recognition of an important procedural protection unique to revocation proceedings: the Notice of Revocation (the "Notice"). As is clear from the wording of s. 18(1), the process of citizenship revocation begins when the Minister gives notice to an individual of her intention to make a report to the Governor-in-Council; the document containing this information is the Notice. The leading case regarding the importance and effect of the Notice is Dueck. ${ }^{47}$ In order to understand the reasons in Dueck, it is useful to make reference to Rule 920 of the former Federal Court Rules and the history of the proceedings in the case.

The former Rule 920 of the Federal Court Rules provided in part that:

The following provisions shall apply to the hearing of a case (section [18] of the Act);

(a) upon receipt of a request to the Minister by a person (hereafter the "person") in respect of whom the Minister intends to make a report pursuant to section [10] of the Act that the case be referred to the Court, the Minister shall, if he decides to refer the case to the Court, forward a copy of the request and of his reference to the Court to the Registry;

(b) the Minister shall, within 14 days thereafter, file in the Registry and serve on the person...

(iii) a summary of the facts and evidence on which the Minister intends to rely at the hearing of the case... ${ }^{48}$

On January 27, 1995, the Minister sent Dueck the following Notice:

[T] he Minister of Citizenship and Immigration intends to [make] to the Governor-in-Council a report within the meaning of ss. 10 and 18 of the Citizenship Act, R.S.C. 1985, c. C-29, as amended and s. 19 of the Canadian Citizenship Act, R.S.C. 1952, c. 33, as amended, on the grounds that you have been admitted to Canada for permanent residence and have obtained Canadian citizenship by false representations or fraud or by knowingly concealing material circumstances in that you failed to divulge to Canadian immigration and citizenship officials your membership in the Selidovka district raion police in German occupied Ukraine during the period 1941 to 1943, and your participation in the executions of civilians and prisoners-of-war during that time....9.9

Pursuant to Rule 920(b)(iii), the applicant Minister then served and filed with the Court a statement of the summary of the facts and evidence (the "Summary") upon

See Luitjens No. 2, supra note 16.

Supra note 3.

Federal Court Rules, supra note 40 at r. 920 [emphasis added].

Canada (Minister of Citizenship and Immigration) v. Dueck (1998), 154 F.T.R. 241 at 243 (T.D.)

Noël J. [hereinafter Dueck No. 2] [emphasis in original]. 
which she intended to rely at the hearing of the case. This Summary contained allegations that Dueck was a member of the local Selidovka Ukrainian police, during the German occupation and that, as required, he acted as an interpreter for the occupying forces. ${ }^{50}$ In addition, there were several specific allegations that Dueck had participated in the arrests and executions of civilians, including Jewish families and former military personnel. ${ }^{51}$ At the beginning of the hearing, the applicant withdrew all specific allegations of criminal activity against Dueck with the exception of involvement in a hostage taking by the auxiliary police in the winter between 19421943. As a result, Dueck brought a motion for summary judgment on the basis that the Notice alleged one cumulative ground for revocation ${ }^{52}$ and that, after abandoning the allegations with respect to criminal activity, the Minister could no longer prove her case. $^{\text {s3 }}$

In the context of this motion, Noël J. held that the Notice has an important role in defining the scope of the reference to the Court. Pursuant to ss. 18(1)(a) and (b) of the $A c t$, the Notice presents the individual with a choice either not to respond to the Notice, thus allowing the Minister to make the report to the Governor-in-Council, or to request a reference to the Court. Faced with this choice, the individual must know what is alleged to have been "concealed or misrepresented" and, thus, the Notice must set out the "essence of the alleged false representation." the detailed Summary is to be filed within fourteen days after the filing of the reference and is to advise the individual of the facts and evidence upon which the Minister intends to rely in proving "the case." According to the Court:

It is therefore apparent that the matter referred to the court pursuant to $\mathrm{s} .18$ of the $A c t$ is "the case" as set out by the Minister in the Notice and that the Minister is not entitled to make a report unless she is in receipt of the decision of the court on "the case" referred to it. It follows that it is not open to the Minister in a reference before this court to seek a determination on an issue that does not come within "the case" set out by the Minister in her Notice."

According to Noël J., however, while the Notice defines "the case," it does so in a summary manner and the issue is whether, on a "fair reading" of the Notice, an allegation comes within its scope. ${ }^{57}$ Following this reasoning, Noël J. held that an independent allegation of membership in the Selidovka police came fairly within the Notice. While the allegations of membership in the Selidovka district police and participation in the executions of civilians and prisoners of war between 1941 and 1943

Ibid. at 244.

For a reproduction of the relevant paragraphs of the Applicant Minister's Summary, see ibid. at 244-45.

The failure to divulge "your membership in the Selidvoka district (raion) police in German occupied Ukraine during the period 1941 to 1943, and your participation in the executions of civilians and prisoners-of-war during that time...," ibid. at 250.

See ibid. at 247-48 for a full discussion of the Minister's position.

Ibid. at 249.

It is of note, however, that pleadings normally contain only facts and not the evidence to be relied upon in proving these facts.

Dueck No. 2, supra note 49 at 250.

Ibid. 
were linked by the word "and" and not "or," to read the Notice as containing one cumulative allegation would have "subject[ed] the Notice to a reading that is overly strict." 58

While the respondent was not successful on this motion, the Court's construction of the Notice had an important effect on the ultimate decision in the case. Based on the evidence adduced at the reference, the Court found as fact that Dueck was not a policeman during the occupation but was an interpreter for the German authorities and later held an important civic position. ${ }^{59}$ The Court rejected the argument that the Minister could seek a finding with respect to any act of collaboration, or that the Summary could widen the scope of the Notice to include allegations that Dueck had acted as an interpreter for members of the German occupying forces and served with the local police in the Jelanez District. According to the Court:

What does not fall within the ambit of the notice is either an independent allegation that the respondent was a translator for the occupying forces or the allegation that he served in the police in Jelanez.

As I ruled earlier, the summary of facts and evidence is intended to outline the facts and evidence to be relied upon by the applicant to establish the allegation contained in the notice. The applicant cannot, under the guise of communicating her means of proving the allegation, extend the notice beyond what it contemplates. However one chooses to read the notice in this case, it never contemplated that the applicant would seek the revocation of the respondent's citizenship because he failed to disclose his activities as a translator or his membership in the police in Jelanez. ${ }^{00}$

As a result, the Court concluded that the Minister had not brought her case against Dueck within the scope of the Notice.

This reasoning was followed in Podins, where the Minister inter alia alleged that the respondent, Podins, was a member of a Latvian Security Police Battalion and had voluntarily served as a member of the Latvian Legion, also known as the Waffen SS. ${ }^{61}$ The Notice, however, alleged as follows:

[Y]ou failed to divulge to Canadian immigration and citizenship officials your collaboration with German authorities in Latvia during the period 1941-1943, as a member of the Latvian Auxiliary police, a local Auxiliary police under the command of the Germans and your work, in such capacity as a

Ibid.

Dueck, supra note 3 at 26-27.

Ibid. at 28. Further, the Court rejected the argument that the reference to "membership" in the police was broad enough to encompass an individual who acted as an interpreter for the Selidovka police. According to the Court, the evidence was that Dueck had translated for the Gendarmerie (part of the Order police) rather than for the chief of police in Selidovka. Further, even if it could be said that the respondent acted as a translator for the auxiliary police, the evidence did not support the contention that interpreters for the police were considered "members" of the police. Finally, the Court noted that the summary of facts and evidence stated that the respondent "acted as an interpreter for members of the German occupying forces," not the Selidovka police. See Dueck at 28-30.

Podins, supra note 7 at para. 5. 
concentration camp guard in the so-called "Valmiera replacement prison", in Latvia, during the same period. $^{62}$

McKeown J. construed the Notice as alleging collaboration in respect of membership in the Latvian Auxiliary Police and the respondent's "work in such capacity" in the Valmiera replacement prison. As a result, the allegation of membership in the Waffen SS fell outside the scope of the Notice, and McKeown J. held it unnecessary to make findings of fact on this issue.

The final case which has thus far addressed the importance of the Notice is Canada (Minister of Citizenship and Immigration) v. Odynsky. ${ }^{63}$ In this case the Notice advised the respondent that the Minister sought to make a report regarding deception about the following activities:

...collaboration with German authorities and your engagement in activities connected with forced labour and concentration camps during the period 1943-44, as a guard at the Trawnicki Training Camp and later at the Poniatawa Labour Camp, in Poland. ${ }^{\text {(t) }}$

On an interlocutory motion, the respondent sought to have certain portions of an expert report held inadmissible on the basis that it discussed "activities at times and places other than those specifically referred to within the Notice of Revocation." 65 MacKay J. found that the Notice included two separate allegations: the broad allegation of "collaboration with German authorities" and the more specific allegation of being a guard in specific forced labour and concentration camps. MacKay J. held that while the allegation of collaboration itself would be insufficient notice, particularization of this allegation was provided by the Summary. ${ }^{66}$ Since this allegation was broad enough to capture all the facts alleged in the Summary, MacKay J. held that the only inadmissible portion of the report was that about which no fact was alleged.

The decisions in Dueck, Podins, and Odynsky demonstrate that the wording of the Notice can have an extremely important impact both on the breadth and success of the Minister's case against an individual. It is relevant to note that the proceedings in these cases were all commenced under the old Federal Court Rules, the provisions of which were substantially different than the new rules in respect of citizenship revocation proceedings. There are two changes of note under the Federal Court Rules, 1998. ${ }^{67}$ First, the rules relating to actions are now specifically made applicable to revocation proceedings and, as a result, there is now an exchange of "true" pleadings. ${ }^{68}$ In an action, it is normally pleadings which define "the case" and as has been stated by the Federal Court of Appeal:

Ibid. at para 11 [emphasis added].

[1999] F.C.J. No. 746 (T.D.), online: QL (FCJ) [hereinafter Odynsky]. At the time of writing, the ultimate decision in Odynsky has not been released.

Ibid. at para. 21 [emphasis added].

Ibid. at para. 13.

The summary, in turn, might be refined by discoveries and admissions by the Minister (ibid. at para. 23).

Supra note 40.

lbid. at r. 169(a), 171. 
In general, the Court expects parties to adhere to the rules of pleading so that each side will know the case the other is required to meet when it comes to trial. It may be said that it is the facts as pleaded and the issues as defined in the pleadings which determine the relevancy of evidence whether oral or documentary; and if the latter, whether a document must be produced before trial. ${ }^{69}$

Second, in contrast to the old procedure, it does not appear that the Minister is required to send a copy of the individual's reference request or the reference itself to the Registry of the Court; as such, the new rules do not appear to explicitly require that the Notice be sent to the Court. ${ }^{70}$

In spite of these changes, it is probable that the Courts will continue to find that it is the Notice that defines "the case." This is because, even under the new rules, before the actual proceedings are commenced and thus pleadings exchanged, the individual to whom the Notice is sent must still determine whether to request a reference to the Court. Following the reasoning of cases discussed above, in order to make this clearly important decision, the individual must be aware of the "essence" of the allegations against him or her. As such, while the pleadings later exchanged may state the specific facts alleged and narrow the issues in dispute, the Notice will still remain the document which ultimately determines the ambit of the proceedings.

If the above analysis is correct, the Notice will be of continued importance in revocation proceedings and this has significant implications for the Minister. First and foremost, it is important to recognize that the Notice defines the jurisdiction of the Court in respect of which a determination can be made. Thus, even if the Minister is able to prove facts which might otherwise be sufficient grounds for citizenship revocation, if these facts fall outside the ambit of the Notice, they cannot be the basis for a positive determination by the Court under s. 18(1) of the Act. This would apply both in respect of an allegation that a respondent obtained his or her citizenship by deception and that, at the time of application for citizenship, the individual wrongly declared him or herself to be of good character. ${ }^{71}$ Further, in the event that a court were to make a finding of fact with respect to criminal or other prohibited activity which fell outside the Notice, the Minister could not make a report to the Governor-inCouncil on this basis. While this may appear to be a technical legal point, it should be remembered that the wording of the Notice in Podins prevented findings of fact on the serious allegation of membership in the Waffen SS.

Thus, an important consideration from the perspective of the Minister is the wording of the Notice. In order to ensure that the Minister's case comes within the Notice, there appears to be at least two options open to her. The first is to draft the Notice in broad terms to allow some flexibility in respect of the case to be proven and upon which the Minister can make a report. For example, based on the Court's decision in Odynsky, it Canada (1994), 176 N.R. 149 (F.C.A.). 
would appear wise for the Minister to include an independent allegation of "collaboration with the Germans" in WWII collaboration cases. On the reasoning in Odynsky, as long as the Minister supports a broad allegation in the Notice with sufficient particulars in the statement of claim, adequate notice will have been provided.

Having said this, the courts will likely place some limits on how broadly the allegations in the Notice may in fact be drafted. While it is not suggested that the courts should or will adopt an overly technical interpretation of the Notice, it is at least arguable that a general allegation of "collaboration" provides insufficient notice to an individual faced with a decision under s. 18(1); it is important to remember that when the individual makes the decision, he or she will not have before them the particulars contained in the statement of claim. As will be discussed below, collaboration can have a number of meanings, and such an allegation could potentially refer to a multitude of instances of action or inaction by an individual. If it is in fact the Notice that defines the Minister's case, it cannot be drafted so broadly and capable of so many interpretations that the individual does not have true notice of the allegations against him or her.

The second option available to the Minister is to amend the Notice where, for example, it is discovered that the evidence with respect to an individual does not correspond to the Notice. An amendment has occurred in at least one case to date. ${ }^{72}$ While the courts have yet to adjudicate upon the propriety of such an amendment, the most important issues will be its timing and scope. Similar to the issues regarding the breadth of the Notice, it is clear that the courts will want to ensure that the individual has notice of the allegations against him or her as early as possible so that he or she is in a position to prepare accordingly. While this is not a criminal proceeding and the Notice does not act as an indictment, the courts are very aware both of the serious nature of the allegations in this type of case $^{73}$ and the fact that it is citizenship, a "very "valuable privilege," "74 which is a stake. In this context, the courts will likely seek to ensure that any prejudice in knowing the case to meet is limited. ${ }^{75}$

\section{Appeals}

The final procedural issue is the availability of appeals in revocation cases. Section 18(3) of the Act provides as follows:

A decision of the Court made under subsection (l) is final and, notwithstanding any other Act of Parliament, no appeal lies therefrom. ${ }^{76}$

$72 \quad$ Vitols, supra note 5.

73 See Bogutin, supra note 20 at 29.

74 Tobiass, supra note 29 at 435 and Benner v. Canada (Secretary of State), [1997] I S.C.R. 358 at 395.

is This would appear to be particularly important where the Minister or the respondent seek to take Commission evidence abroad. Rules 271-273 of the Federal Court Rules, 1998, together allow, upon a motion, for the taking of evidence outside of Canada and, unless the Court orders otherwise, the use of this evidence at trial without further proof. 
Section 27(1) of the Federal Court $A c t^{77}$ provides generally for appeals from the Trial Division to the Court of Appeal from a final judgment, judgment on a question of law determined before trial, interlocutory judgment, or determination on a reference made by a federal board, commission, or other tribunal or the Attorney General of Canada.

The scope of s. 18(3), and the apparent conflict between it and the provisions of the Federal Court Act, has been considered both by the Federal Court of Appeal and the Supreme Court of Canada. In Luitjens No. 2 it was held that there is no conflict between these provisions since, according to the Court of Appeal:

[T]his decision is not a "final judgment" of the court, nor is it an "interlocutory judgment". Although the decision followed a hearing at which much evidence was adduced, it was merely a finding of fact by the court, which was to form the basis of a Report by the Minister and, eventually, a decision by the Governor-in-Council, as described by ss. 10 and $18(1)$. The decision did not finally determine any legal rights. ${ }^{78}$

This passage reflects the essence of the reasons of the Court of Appeal in Luitjens No. 2, which is that s. 27(1) of the Federal Court Act is inapplicable in respect of a citizenship revocation decision, because such a decision determines no legal rights. In addition, Linden J.A. stated that even if the determination by the Court was a final or interlocutory judgment, there would still be no conflict since s. 18(3) specifically excludes the operation of any other Act of Parliament, of which the Federal Court Act is one.

In Tobiass, ${ }^{79}$ the Supreme Court addressed whether s. 18(3) of the Act ousts the jurisdiction of the Federal Court of Appeal to hear an appeal of its Trial decision granting a stay of proceedings. The ratio of Tobiass on this point is that a decision granting a stay of proceedings is not a decision "under" s. 18(1), but rather is a decision under s. 50 of the Federal Court Act.$^{80}$ According to the Supreme Court:

This conclusion flows from the wording of $s$. 18. Section $18(1)$ refers to a very particular kind of decision: a decision as to whether a person "has obtained, retained, renounced or resumed citizenship"

R.S.C. 1985 , c. F-7, as am. by S.C. 1990 , c. 8 , s. 7.

Luitjens No. 2, supra note 16 at 175.

In Tobiass, supra note 29, the Supreme Court of Canada decided, inter alia, that the appearance of judicial independence in the cases of Dueck No. $l$, Tobiass No. $l$, and Oberlander (supra note 40) was damaged due to a meeting between the Chief Justice of the Federal Court and the Assistant Deputy Attorney General in charge of civil litigation at the Department of Justice. The Supreme Court decided, however, that a stay of proceedings was not appropriate in this situation. It returned the cases to the Federal Court - Trial Division for a hearing before a judge of the Trial Division who had nothing to do with the factual circumstances underlying the appeal. For a further discussion of this aspect of the decision, see C. Barr, "Judicial Independence and Judicial Administration in the Tobiass Case" (1998) 9:2 Constitutional Forum 48.

Supra note 77. Section 50(1) reads:

The Court may, in its discretion, stay proceedings in any cause or matter,

(a) on the ground that the claim is being proceeded with in another court or jurisdiction; or

(b) where for any other reason it is in the interest of justice that the proceedings be stayed. 
by false pretences. However, a stay of proceedings is entered for reasons which are completely unrelated to the circumstances surrounding the obtaining, retaining, renouncing or resuming of citizenship. Indeed, a decision to order (or not to order) a stay of proceedings is different from the type of determination that the Court is called upon to make under subsection 18(1)."

Further, in contrast to a decision under s. 18(1), a decision granting a stay is a final judgment as it concludes the proceedings.

After deciding the case on this basis, the Supreme Court commented extensively, and in obiter, on the scope of s. 18(1) of the Act. The Supreme Court first noted that, although a literal interpretation of the wording of s. 18(1) may suggest otherwise, either a positive or negative determination by the Court on such a reference may not be appealed. $^{82}$ Second, and importantly, the Supreme Court stated that there was a "great deal of force" to the argument that s. 18(1) applies not only to the ultimate decision as to whether someone obtained citizenship based on deception, but also to all interlocutory decisions which the Court is empowered to make on a reference under $\mathrm{s}$. 18. ${ }^{83}$ According to the Court:

This interpretation of s. 18(1) was adopted by the Federal Court of Appeal in Luitjens, supra, where it held that interlocutory decisions made in the context of [sic] s. 18(1) reference are decisions made "under" s. 18(1). It is not necessary for the purpose of this decision to determine whether this conclusion should be varied. That should only be done in an appeal where the issue arises from the facts."

With respect, the Court of Appeal in Luitjens No. 2 neither decided nor stated in obiter that interlocutory decisions cannot be appealed under s. 18(3). As noted above, the Court decided only that the ultimate decision on a reference under s. 18(1) is not a final or interlocutory judgment for the purposes of s. 27(1) of the Federal Court Act. It further stated that assuming such a decision was a final or interlocutory judgment, s. 18(3) would nonetheless oust the application of the Federal Court Act. As a result, while there is obiter from the Supreme Court that interlocutory decisions are not subject to appeal and a recognition that "finality in citizenship matters" is a valid policy concern, ${ }^{85}$ this is still an open issue which will certainly be revisited by the courts.

Given the enormous stakes for both parties in such proceedings, it is likely that the jurisprudence will recognize certain circumstances in which appeals will be allowed. While the ultimate decision may be factual, there are important and often complex legal issues which arise in the context of the proceedings leading up to and during the hearing of the reference itself; these may have an important impact on the ultimate "factual" finding in a case. These issues may be evidentiary in nature or relate more specifically to citizenship and immigration law, such as the duty of a potential

Tobiass, supra note 29 at 413 .

The wording of s. $18(1)$ on its face appears only to contemplate a positive finding by the Federal Court - Trial Division.

Tobiass, supra note 29 at 414 .

Ibid. at 414-15.

Ibid. at 415 . 
immigrant to disclose information absent relevant questions. ${ }^{86}$ Particularly, where there are two or more conflicting decisions on the same legal issue, it is questionable whether all decisions related to a s. 18(1) proceeding should be characterized as "factual" and, therefore, not subject to appeal.

One circumstance in which an appeal or judicial review will certainly be allowed is where the decision of the Court is outside its jurisdiction and thus not a decision "under" s. 18(1). It has already been held that a judge rendering a decision in a citizenship revocation proceeding who was found to be biased would be acting without jurisdiction and that the decision would therefore be subject to review. ${ }^{87}$ Another jurisdictional issue, which on this reasoning would certainly be subject to review, is the Court's construction of the Notice of Revocation. Since, as noted above, the Notice goes both to the jurisdiction of the Court to decide and that of the Minister to make a report to the Governor-in-Council, a construction of the Notice which is either too broad or too narrow ${ }^{88}$ would be subject to review. This would appear to be the case regarding any issue that goes to the ability of the Court to decide. ${ }^{89}$

This issue will be discussed in detail in this article under the heading "The Duty of Candour." Canada (Minister of Citizenship and Immigration) v. Katriuk (1999), 235 N.R. 305 (F.C.A.). This is by analogy to an appeal from a decision not to grant a motion for a stay of proceedings. As noted by the Court in Tobiass, supra note 29 at 416 :

It should be noted that, even if s. 18(1) of the Citizenship Act were to be interpreted as encompassing not only the final determination as to whether citizenship was obtained by false pretences but also any decisions related to this determination, an exception should be made for a decision to deny a motion for a stay of proceedings. It is arguable that a decision denying a stay of proceedings is "related" to the question of whether citizenship was obtained by false pretences insofar as it has the effect of allowing the inquiry on the merits to proceed. However, it would appear to be fundamentally unfair, and contrary to the rules of natural justice, to allow appeals to be taken from a decision to order a stay of proceedings but not from a decision refusing to order a stay. Such a result could not have been intended by Parliament. [emphasis added]

Further, the Supreme Court of Canada expressly left open the question of whether, in certain circumstances, there may be an appeal directly to the Supreme Court from a decision of the Trial Division in a citizenship revocation proceeding. In particular, the Court noted that, during the oral hearing in Tobiass, there was doubt whether s. 18(3) would have the effect of preventing appeals to the Supreme Court pursuant to s. 40 of the Supreme Court Act, R.S.C. 1985, c. S-26, as am. by S.C. 1990, c. 8, s. 37, if this section was applicable. This section reads:

Subject to subsection (3), an appeal lies to the Supreme Court from any final or other judgment of the Federal Court of Appeal or of the highest court of final resort in a province, or a judge thereof, in which judgment can be had in the particular case sought to be appealed to the Supreme Court, whether or not leave to appeal to the Supreme Court has been refused by any other court, where, with respect to the particular case sought to be appealed, the Supreme Court is of the opinion that any question involved therein is, by reason of its public importance or the importance of any issue of law or any issue of mixed law and fact involved in that question, one that ought to be decided by the Supreme Court or is, for any other reason, of such a nature or significance as to warrant decision by it, and leave to appeal from that judgment is accordingly granted by the Supreme Court.

In this respect, it should be noted that like the Federal Court, the Supreme Court is a creature of statute and that, therefore, to the extent that s. 18(3) operates notwithstanding other Acts of Parliament, appeals allowed under the Supreme Court Act also may be eliminated.

The Supreme Court also did not address whether $\mathbf{s}$. 7 of the Charter provides a basis for an appeal directly to the Supreme Court from a decision under s. 18(1). The Court of Appeal in Luitjens No. 2, supra note 16, rejected the argument that s. 18(3) violates s. 7 of the Charter. As noted above, 


\section{Substantive IsSues in WWII Revocation Cases: CANAdA'S IMmigRation and Citizenship LaW, POLICY, and Practice Post-WWII}

As noted above, the ultimate issue on a citizenship revocation reference is whether the individual, whether by fraud, false representation, or by knowingly concealing material circumstances, was admitted to Canada and ultimately obtained Canadian citizenship. In order for the Minister to meet her burden on this issue in cases alleging WWII collaboration, there are three factual issues to be determined. The first and most obvious is whether the individual against whom the proceedings have been brought actually took part in the alleged acts, whether it be specific war crimes or membership in a collaborationist organization; essentially the question is whether there is information the individual would have sought to hide. The second issue is whether, at the time the individual applied to enter Canada, collaborators generally or those who committed war crimes were classes prohibited from coming to Canada. If not, it becomes arguable that an individual who disclosed having "collaborated" to Canadian immigration officials would still have been admitted. Further, this would not only reduce the chance an individual would have been asked questions or was by law required to volunteer information about such collaboration, but would also bring into question the materiality of any misrepresentation regarding such activities. A third issue, related to the second, is whether individuals applying to come to Canada were systematically screened and asked questions that would elicit information with respect to alleged wartime activities. All these issues go to the ultimate question: Did this individual lie to or deceive immigration officials in order to enter Canada?

While proof on the first issue is difficult as a result of deceased witnesses, a lack of documentation, and fading memories, it is also challenging in respect of the second and third issues. This is because, apart from the testimony of the respondent in the proceedings, there is generally little or no direct evidence about the representations made by the individual upon entry to Canada. This is partially as a result of a government policy to routinely destroy immigration files which would have been completed by individuals upon application for entry to Canada in the post-WWII period. $^{90}$ As a result, Canadian immigration policy and practice at the time the

Linden J.A., at 175 , held that the finding of the Court under s. 18(1) is simply a finding of fact which:

may well form the basis of decisions by others, which may interfere with [the right to life, liberty and security of the person] at some future time, but this decision does not do so [emphasis in original].

Further, according to Linden J.A., even if there was a violation, the principles of fundamental justice do not require appeals at every step in a proceeding. In Tobiass, the Supreme Court did not specifically comment upon this aspect of the reasoning in Luitjens No. 2 but did approve the characterization of the proceedings as directed at findings of fact only. This is an indication that the Supreme Court may not be inclined to find a constitutional right to appeal in every circumstance.

\$1 For a brief discussion of the Government's file destruction policy, see Canada (Minister of Citizenship and Immigration) v. Katriuk, [1999] F.C.J. No. 216 (T.D.), online: QL (FCJ). A motion for a stay of proceedings was brought on the basis that the destruction of documents by the Government violated the s. 7 Charter rights of Katriuk to full answer and defence. This motion was denied. 
individual entered Canada must generally be ascertained by way of documentary and testimonial evidence not directly related to the case of the individual. The Minister must demonstrate that, because there was a sufficiently uniform system for screening immigrants post-WWII, the respondent would not have been admitted to Canada or gained Canadian citizenship absent deception.

This section of the article will focus on the second and third factual issues, examining the jurisprudence on whether collaborators were in fact a prohibited class and whether immigration officials were routinely and systematically screening applicants for admission to Canada from Europe. In addition, two important legal issues have arisen in this context: whether immigrants in the immediate post-WWII period had a duty of candour and whether legal authority existed for immigration officials to reject applicants on the basis of collaboration.

\section{a. Collaboration}

While legislation and orders-in-council in force in the immediate post-WWII period provided the broad legal framework within which it was determined who could and could not enter Canada, there were no explicit provisions therein ${ }^{91}$ prohibiting the entry of collaborators generally from entering Canada. As a result, a major issue in all revocation cases involving WWII collaboration is whether these individuals were in fact prohibited from coming to Canada.

The position of the Minister in Dueck, Kisluk, Vitols, Katriuk, and Podins was that, in the post-WWII period, the applicable security screening criteria prohibited anyone who had collaborated with the German forces from immigrating to Canada; ${ }^{92}$ security screening was concerned with classes who were perceived to be a risk to Canada. As noted above, this is a factual issue and the courts have found that the security screening criteria changed over time; thus, in terms of collaboration, it matters when individuals applied to enter Canada. Further, as is the case with any factual issue, in light of the evidence before the court, representations made by counsel, and the approach adopted by the court, different conclusions on similar issues may result. In order to explore these two propositions, the five decisions released in 1998-1999 will be examined in order of the date upon which the respondent applied to immigrate to Canada. While these cases are clearly important from a legal perspective, they are also of great interest from a historical perspective as they shed some light on Canada's approach to immigration in the immediate post-WWII period. ${ }^{93}$

It is arguable, and has in fact been argued, that there was legal authority for Canadian immigration officials to prohibit the entry of such individuals to Canada. See the discussion in section $D$ below.

'2 $\quad$ See e.g. Dueck, supra note 3 at 8; Katriuk, supra note 6 at para. 6; Vitols, supra note 5 at 197.

"3 It is, of course, not the case that the findings of fact in these cases will necessarily reflect the 'truth' of what was occurring in the post-WWIl period; it may or may not. In this respect, it is important to note that both the absence of evidence, documentary and testimonial, due to the passage of time, and the laws of evidence affect such findings of fact. 
The case involving the earliest application for entry to Canada is Dueck, the date being July $1948 .{ }^{94}$ On the evidence before him, Noël J. concluded that at this time it was unlikely the applicable security screening criteria would have prohibited the entry to Canada of all collaborators. In 1948, the situation with respect to security screening was "in a state of flux and rapid evolution"9s and the RCMP, in charge of security screening, ${ }^{96}$ was at once "struggling to comply with Cabinet's direction to maintain security screening without impeding the flow of immigrants." 97

According to Noël J., in July of 1948, RCMP security officers were screening and rejecting applicants based on oral instructions from RCMP headquarters; it was not until mid-1948 that immigration officials decided to create a written list of security screening criteria. ${ }^{8}$ On July 7, 1948, Major Wright, the officer in charge of security screening operations in Europe, was asked by his superior to produce a list of the "causes on which our men presently reject applicants." showed that the RCMP could not identify with accuracy the screening criteria being applied in July $1948 .{ }^{100}$ The list prepared by Major Wright was contained in a letter dated August 11, 1948, and, according to Wright, showed the "causes for which our men presently reject applicants either in the London office, in Germany or elsewhere." 101 The "Reasons for Rejection" listed in the letter are as follows:

(a) COMMUNIST. Known Communist. Suspected Communist. Communist Agitator or Suspected Communist Agent.

(b) Member of SS or German Wehrmacht. Found to bear mark of SS Blood Group (Non Germans).

(c) Member of Nazi Party.

(d) Criminal (known or suspected). Gambler.

(e) Prostitute.

(f) Black Market Racketeer.

(g) Evasive and untruthful under interrogation.

(h) Failure to produce necessary documents as to time of entry and residence in Germany. These documents are familiar to all screening officers.

(i) False Presentation; - use of false or fictitious name.

Dueck, supra note 3 at 30 . The application was made in Austria.

Ibid. at 48.

These officers were known as security officers and visa control officers.

Dueck, supra note 3 at 48.

Ibid. at 49.

Ibid.

Ibid.

Ibid. at 50 . 
(j) After careful interrogation and deliberation is considered not a fit and proper person to be granted entry into Canada. This covering evidence received (in Germany) to the effect that applicant was disincline [sic] or unwilling to work, and generally lazy. ${ }^{102}$

Noël J. noted that this list contained no "blanket prohibition" against collaborators, but rather "specific instances" of collaboration. This list suggested that, in July 1948, the prohibition against collaborators was intended only for those coming within the classes enumerated in (b) and (c). ${ }^{103}$ As such, the prohibition against collaborators was much narrower than the blanket prohibition suggested by the Minister.

Of further interest is the finding that, as a result of comments by Major Wright's superiors at headquarters, the list was broadened. Its amendments are reflected in the following list dated November 20, 1948:

(a) Communist, known or strongly suspected. Communist agitator or suspected Communist Agent.

(b) Member of SS or German Wehrmacht. Found to bear mark of SS Blood Group (NON Germans).

(c) Member of Nazi Party.

(d) Criminal (known or suspected).

(e) Professional gambler.

(f) Prostitute.

(g) Black Market Racketeer.

(h) Evasive and untruthful under interrogation.

(i) Failure to produce recognizable and acceptable documents as to time of entry and residence in Germany.

(j) False presentation; use of false or fictitious name.

(k) Collaborators presently residing in previously occupied territory.

(I) Member of the Italian Fascist Party or of the Mafia.

(m) Trotskyite or member of other revolutionary organization. 


\section{NOTE}

Any general information to the discredit of the applicant but which is not a security matter, such as nationality, applicant being disciplined or unwilling to work, etc., should be reported to the Immigration Visa Consul or Officer for his attention. ${ }^{104}$

Notable is the addition of paragraph (k), "collaborators presently residing in previously occupied territory." According to Noël J., this list demonstrated that it was not until November 20,1948, after the respondent applied to enter Canada, that this was a prohibited class. ${ }^{105}$

Further, Noël J. rejected the Minister's argument that the words "presently residing in previously occupied territory" in paragraph $(k)$ were superfluous and that this prohibition was a general one against collaborators, irrespective of residence. In particular, he found that this prohibition was "a focused criterion directed primarily towards wording [sic] off Soviet infiltration."106 According to the evidence on crossexamination of one of the Minister's experts, former collaborators still residing in a previously occupied territory were possible targets for Soviet coercion; if their collaborationist history was not common knowledge, the Soviets could exploit this weakness. ${ }^{107}$ On the evidence, Noël J. found that communism was the prime security concern of Canadian officials ${ }^{108}$ and that it was in this context that the qualifying words "presently residing in previously occupied territory" had a "rational and indeed eminently understandable" 109 meaning in 1948.

As a result, according to the analysis of Noël J, in July 1948, the only collaborators prevented from entering Canada on security grounds were members of the SS, German Wehrmacht, or the Nazi Party. In November 1948, when the prohibition against collaborators was broadened, it was directed not towards collaborators generally but rather to those coming within the wording of paragraph (k). Noël J. found that the respondent was not included in those barred from entry to Canada in July $1948 .^{110}$

An interesting contrast to this analysis is provided by the case of Kisluk, which involved an application for entry in December 1948 from Butzbach, Germany. As the November 20,1948, list was in place and the respondent was found to have applied from a non-previously occupied territory (Germany), important in Kisluk was the meaning to be given to paragraph (k). On a review of the evidence, Lutfy J. accepted the Minister's argument and held that, despite the qualifier "previously residing in previously occupied territory," paragraph (k) served as a prohibition against the entry 
of collaborators per se, regardless of their place of residence. On this point, Lutfy J. concluded that:

[I]n December 1948, Nazi collaborators would have been screened as undesirables or security risks by the visa control [RCMP] officers. I make this finding despite the wording of paragraph (k) ("collaborators presently residing in previously occupied territory") in the R.C.M.P. memorandum of November 20, 1948.

In my view, too many other documents, prior and subsequent to December 1948, speak of the concern with respect to Nazi collaborators, without any qualifying words concerning where they were presently residing. On the basis of these documents, the I.R.O. [International Refugee Organization] application forms requesting residential and employment information since 1938 and the evidence of Messrs. Kelly and Cliffe, some of which is hearsay and must be closely scrutinized, I find that, in December 1948, Canada's immigration screening was as much concerned with Nazi collaborators being processed through I.R.O. displaced person centres in Butzbach, Germany and elsewhere, as with Nazi collaborators "presently residing in a previously occupied territory"."'

This passage raises interesting issues and highlights some of the differences in approach in Kisluk and Dueck. First note that Lutfy J. had before him evidence from two former RCMP security officers, Donald D. Cliffe, who started work in Europe in March 1951, and William Kelly, who worked in London, England, between June 1951 and 1954. ${ }^{112}$ There was no objection to their evidence ${ }^{113}$ and both testified that, despite the wording of paragraph ( $k$ ), collaborators would be excluded whether residing in a previously occupied territory or not. ${ }^{114}$ In contrast, based on an objection, in Dueck the evidence of Mr. Kelly was ruled inadmissible, ${ }^{115}$ and, as a result, counsel for the Minister did not call Mr. Cliffe to testify. Thus, in this respect, there was very different evidence before each judge. Second, in stating his reluctance to draw conclusions from any one government document, apparently referring to the November 20,1948 list, on the basis that such evidence is similar in nature to the hearsay evidence of the security officers, Lutfy J. indicates the framework within which he

Kisluk, supra note 4 at paras. 130-31 [footnotes omitted]. A displaced person was an individual who was driven from his or her home due to the circumstances of war (ibid. at para. 106).

Ibid. at paras. 123, 126.

Ibid. at n. 106.

Ibid. at paras. 124, 127-28.

Canada (Minister of Citizenship and Immigration) v. Dueck, [1998] F.C.J. No. 1541 (T.D.), online: QL (FCJ). The proposed testimony of Mr. Kelly regarding the applicable security screening criteria was found to be inadmissible hearsay according to the test set out by the Supreme Court of Canada in $R$. v. Khan, [1990] 2 S.C.R. 531 and $R$ v. Smith, [1992] 2 S.C.R. 915. While the Court in Dueck stated that it was arguable that the criterion of necessity had been met as no security officer who was in Europe in 1948 was available to testify, the evidence was found not to be reliable; this was because there was no evidence regarding to whom the witness spoke to gather his information or the "particular circumstances of the people spoken to." The evidence was found to be additionally unreliable as Mr. Kelly would have been testifying regarding what he learned in 1951 about the situation as it prevailed in 1948. In respect of the documents Mr. Kelly consulted, double hearsay would be involved and reliability would be questionable. Finally, it was found that the testimony of Mr. Kelly regarding the security screening criteria in 1951 would only be relevant to the extent that it established a "link" with the criteria in 1948. This "link," however, could only be established through inadmissible hearsay evidence. 
approached an analysis of the evidence; this was to look at the evidence globally. Thus, in addition to the evidence of the security officers and the November 20, 1948 list, Lutfy J. emphasized a number of documents, mainly Cabinet and Security Panel documents, ${ }^{116}$ and noted that they discussed a prohibition on collaborators generally, without the qualifying words of paragraph (k). Lutfy $\mathrm{J}$. further emphasized the importance of Cabinet Directive No. 14 (Rejection of Immigrants on Security Grounds), issued in 1949, which provided in part that:

Displaced persons and certain classes of prospective immigrants desiring to enter Canada are investigated under established procedures by the R.C.M. Police. Persons in specified categories (i.e., Communists, members of the Nazi or Fascist Parties or of any revolutionary organization, "collaborators", and users of false or fictitious names or documents) are regarded as inadmissible under the Immigration Act and are refused a visa."17

Notably, this Directive referred to collaborators generally and, according to Lutfy J., since a Cabinet Directive generally reflected government policy and is distributed to many government institutions, it deserved greater weight than the memoranda of single individuals. Thus, whereas Noël J. found the plain wording of paragraph (k) consistent with the government's concern to prohibit the entry of a narrow class of collaborators, Lutfy $\mathrm{J}$. held that the screening for collaborators was in fact much broader than that indicated by paragraph $(\mathrm{k})$.

With regard to the kinds of activities that would constitute collaboration, ${ }^{118}$ Lutfy J. pointed to the evidence of one of the security officers, Mr. Cliffe, who stated that:

[A] collaborator would be a person of that nationality [French, Belgian, Dutch, Danish, or Norwegian] that, when the Germans invaded, they decided to assist the Germans. And I don't mean by delivering groceries to them, but I'm talking about actively involved to the peril of their fellow countrymen.

I would be looking for people who actively supported the Germans, after they invaded their country, and who assisted the Germans in rounding up some of their own fellow countrymen. ... That's a collaborator. ${ }^{119}$

According to Mr. Cliffe, the auxiliary police in the Ukraine were collaborators. ${ }^{120}$ In concluding that the activities of the respondent as a railway guard and auxiliary police officer would be collaboration "within the meaning of the government documents and as understood by the R.C.M.P. security officers in December 1948,"121 Lutfy J. appears to have accepted the evidence of Mr. Cliffe on the meaning of collaboration.

The Security Panel was an interdepartmental committee which advised Cabinet about various security issues in the post-WWII period.

Kisluk, supra note 4 at para. 100.

This issue was not addressed in Dueck.

Kisluk, supra note 4 at para. 124.

Ibid. at para. 125.

Ibid. at para. 185 . 
In contrast to Dueck and Kisluk, Vitols, Katriuk, and Podins all involve applications which occurred in the 1950s. In Vitols, the respondent applied to enter Canada in 1950 from Germany and thus, as was necessary in both Dueck and Kisluk, McKeown J. examined the meaning of paragraph $(k)$ of the November 20, 1948 list. ${ }^{122}$ Nicholas d'Ombrain was an expert witness on behalf of the Minister and according to McKeown J.:

\begin{abstract}
Mr. d'Ombrain, in cross-examination...discussed category $(\mathrm{k})$ in particular. He stated that the category's meaning was completely unclear to him. He agreed that it did not seem to include a displaced person in Germany, because Germany could not be called a previously occupied territory. Mr. d'Ombrain stated that he felt that the phrase was an example of the very imprecise language used by the RCMP to say something very simple: collaborators were not allowed to come in to Canada. However, as category (k) shows, this was not clearly communicated
\end{abstract}

The critical issue is how the "meaningless" phrase in category (k) of the screening criteria was interpreted and applied in the field by the Canadian visa control officers. ${ }^{123}$

As was the case in Kisluk, both Kelly and Cliffe testified about the applicable security screening criteria. In Vitols, however, Keelan, a security officer in Germany from 1950-1951, ${ }^{124}$ also testified that, in interviewing potential immigrants, he would not apply paragraph (k); according to Keelan, if he was interviewing a displaced person in Germany, he could not have been interviewing them in a previously occupied territory. He also gave evidence that the application of category (k) was in his discretion. ${ }^{125}$ In light of a 1952 Security Panel memorandum indicating that, while immigration policy prohibited the entry of collaborators to Canada, "cases [had] so far been dealt with on their individual merits or demerits," 126 and the fact that Keelan was the only security officer who had actually been in the field in 1950 who testified, McKeown J. found his evidence credible.

Further, based on the evidence, McKeown J. was unable to determine whether there were multiple understandings of the term collaborator when the respondent entered Canada. While one expert historian and Kelly, a security officer, appeared to link collaboration to the actions of high ranking officials who had assisted the Germans, another expert historian

tended to define collaborator very broadly so that all those who were subordinate to the Germans, no matter how low down the chain, were collaborators. He even considered the reserve forces of farmers, called in to protect the local community, to be collaborators. ${ }^{27}$

122 Vitols was decided in the fall of 1998, before both Dueck and Kisluk.

123 Vitols, supra note 5 at 194-95.

$124 \quad$ lbid. at 188.

125 Ibid. at 195.

126. Jbid.

$127 \quad$ Ibid. at 199 
McKeown J. noted that Canada's definition of collaborator in 1952 included "an element of betrayal, moral turpitude, criminal conviction, or treason."128 Prior to the respondent's security screening, however, security officers were not provided with an interpretation of paragraph $(\mathrm{k})$, and, while the security officers who testified gave evidence that anyone who had served with the occupying forces, "including police battalions, auxiliary police, or the 'Waffen SS," would be excluded, ${ }^{129}$ the wording of paragraph (k) prevented a uniform application by security officers. ${ }^{130}$

While McKeown J. did not come to a finding of fact on the meaning to be given to paragraph (k), he concluded that, in light of the evidence of Keelan and the fact that he did not know which security officer interviewed Vitols nor whether there had been numerous understandings of the notion of collaboration, the Minister had failed to meet her burden to demonstrate that there was a consistently understood and applied notion of collaboration in 1950. It was not clear whether, on his application for entry, Vitols would have been rejected by security officers despite his involvement as a police officer and a member of the Waffen SS. ${ }^{131}$

In Katriuk, the respondent applied to enter Canada one year later, in 1951, from Paris, France. Nadon J. held that Cabinet had decided, as illustrated by Cabinet Direction No. 14, that collaborators and users of false names or documents should be denied a visa. ${ }^{132}$ The latter category was relevant in this case as Nadon $\mathbf{J}$. found that the respondent had served with the Germans and had entered Canada under a false name. According to Nadon J., "there cannot be any doubt whatsoever" that the RCMP officers in the field had been advised of the security screening criteria. ${ }^{133}$ According to the evidence of the security officers who testified, collaborators included nonGermans who had served with the German army or assisted it against the allies. ${ }^{134}$

Finally, the decision of Podins involved a much later spring 1959 application from London, England. After referring to the November 20, 1948 security screening criteria, as well as Cabinet Directive No. 14, McKeown J. found that in 1950 there was a relaxation of the security screening criteria. It was in this year that the absolute prohibition on German immigration was lifted and, on October 27, 1950, the Security Panel decided that, while German nationals coming within the security screening criteria should be excluded,

Ibid. According to the Concise Oxford Dictionary, 9th ed. "turpitude" is: "Baseness, depravity, wickedness." Black's Law Dictionary, 6th ed., defines "moral turpitude" as:

The act of baseness, vileness, or the depravity in private and social duties which man owes to his fellow man, or to society in general, contrary to accepted and customary rule of right and duty between man and man.... Act or behavior that gravely violates moral sentiment or accepted moral standards of community and is a morally culpable quality held to be present in some criminal offenses as distinguished from others.... The quality of a crime involving grave infringement of the moral sentiment of the community as distinguished from statutory mala prohibita.

129 Vitols, ibid. at 197.

1.10 Ibid. at 198.

i3I Ibid. at 200.

$132 \quad$ Katriuk, supra note 6 at para. 126.

i1) Ibid. at paras. 126-27.

iu Ibid. at para. 128. 
this general ban should not extend to persons in countries occupied by the Nazis during the war who might have become identified with such organisations under pressure from the occupying power. ${ }^{135}$

This appears to be a reference to the voluntariness of collaboration. One month later Major Wright ${ }^{136}$ was informed that, with the exception of members of the SS, Waffen SS, Abwehr, SD, Gestapo, or "other important and dangerous Nazis when identified," members of the Nazi Party per se were no longer a prohibited class. ${ }^{137}$

In May of 1952 the Security Panel agreed to further narrow the security screening criteria, as reflected in the following list:

[T]he following persons should be refused entry to Canada as immigrants:

a) Former members of the S.S., the Sicherheitsdienst, the Abwehr, the Gestapo, and any former member of the Nazi party who, under Allied Control Council Directive No. 38 of 12th October 1946, was classified as a Major Offender or Offender or who, on evidence before a Security Officer, is in his opinion within either of these categories. Particular care should be taken to exclude persons who were responsible for brutalities in concentration or labour camps.

b) Former members of the Waffen S.S. except:

(i) German nationals who joined before the age of 18 , when there are reasonable grounds for believing they were conscripted or joined under coercion.

(ii) Volkdeutsche formerly residing in German occupied territory, whether they were subsequently naturalised German or not, when there are reasonable grounds for believing they were conscripted or joined under coercion.

(iii) Volkdeutsche and other nationalities who were resettled and naturalised German before joining, when there are reasonable grounds for believing that naturalisation was not of their own choosing, and reasonable grounds for believing they were conscripted or joined under coercion.

(iv) German nationals, Volkdeutsche formerly residing in territory not occupied by the Wehrmacht, whether subsequently naturalised German or not, or other nationalities, when any of these persons can satisfy the Security Officer that they were conscripted or joined under coercion.

c) Former collaborators who should be excluded on grounds of moral turpitude, except minor collaborators whose actions resulted from coercion. ${ }^{138}$

1.35 Podins, supra note 7 at para. 127 [emphasis added].

13, As noted above in section IV.A., Major Wright was the officer in charge of security screening operations in post-WWII Europe.

137 Podins, supra note 7 at para. 128.

$138 \quad$ Ibid. at para. 129 [emphasis added]. 
Further, in October of 1955, the absolute prohibition against Germans who had been members of excluded organizations, such as the SS, was eliminated and German members of such organizations would be admitted if their immigration was sponsored by a close relative; former members of the Gestapo, concentration camp guards, and persons, who "in the opinion of an examining officer" were major offenders under Allied Control Council Directive No. 38, however, remained a prohibited class. ${ }^{139}$

McKeown J. found that, in the spring of 1959 , the security screening criteria, to be read along with the May 1952 changes, were as follows:

(a) Communist, known or strongly suspected. Communist agitator or suspected Communist Agent.

(b) Member of Security Service or German Wehrmacht. When non-German found to bear mark of Security Service Blood Group.

(c) Nazi.

(d) Criminal (known or suspected).

(e) Professional gambler.

(f) Prostitute and homosexual.

(g) Black Market racketeer.

(h) Persons who under interrogation are evasive and untruthful.

(i) Failure to produce recognized and acceptable documents as to time of entry and residence in Germany.

(j) False presentation; use of false or fictitious name.

(k) Collaborators.

(l) Member of the Italian Fascist Party or of the Mafia.

(m) Trotskyites or members of other revolutionary organizations. ${ }^{141}$

It is notable that, in relation to WWII activities, this list had two substantial changes in comparison to that of November 20,1948. First, item (c) simply refers to "Nazi" rather than member of the Nazi party, and second, item (k) merely read "collaborators" without the contentious qualifying words. Thus, on a simple reading of the list, one would assume that both categories had been expanded. According to the findings of McKeown J., however, the opposite had occurred. Nazi party membership was only a

140) Ibid at para. 132 [emphasis added]. This list of security screening criteria was prepared by the secretariat to the Security Panel. 
prohibited class where the individual was an "important and dangerous Nazi," and moral turpitude was the test for collaboration, except in the case of a "minor collaborator" who had been subject to coercion. Even the groups listed in paragraph (a) of the May 1952 Security Panel document were only to be excluded if they would be characterized as a Major Offender or Offender under the Allied Control Council Directive No. 38. Thus, according to these findings of fact, by 1959 the prohibition on those who had collaborated with the Germans was narrowed substantially.

This review of the factual findings with respect to collaboration demonstrates that they are very time dependent. As a general proposition based on the above case law, it can be said that the prohibition against collaborators appears to have been at its widest in 1950, thereafter being narrowed substantially. Strictly speaking, however, as evidenced by the different analysis of paragraph (k) in Dueck, Kisluk, and Vitols, such a generalization is dangerous; Kisluk would characterize the general prohibition as commencing in November 1948, whereas Vitols would question its substance even in 1950. In the face of a large number of documents from many different government sources which at times appear contradictory, as well as sometimes conflicting testimonial evidence, it is perhaps not surprising to find the courts arriving at varied conclusions on the issue of the applicable security screening criteria.

\section{B. Security SCReEning in Practice}

Even if the Minister can demonstrate that an individual falls within the applicable security screening criteria, it is still incumbent upon her to demonstrate that in practice these criteria were being applied. As noted above, the ultimate question in a citizenship revocation proceeding is whether the individual in question gained entry to Canada by means of deception. Thus, if it can be demonstrated that, in practice, the respondent may not have been questioned about his wartime history, it is considerably more difficult to prove that he lied or misrepresented himself to gain entry into Canada.

Not surprisingly therefore, the 1998-1999 jurisprudence has demonstrated that an important issue is whether the respondent was asked about his wartime history, either by way of an application form, a personal interview with an RCMP officer, or both; even to a greater extent than the issue of the applicable security screening criteria, this is a highly complex and fact specific issue. Whether and what type of security screening an individual was subject to may depend on various factors such as the date and place of application, the citizenship of the applicant, whether the individual was sponsored by a relative to come to Canada, and whether the individual was in a particular occupational category. Kisluk, Vitols, and Katriuk held that there was a uniform system of security screening which would have applied in the circumstances of the respondent, ${ }^{141}$ while the opposite conclusion was reached in Dueck and Podins. While analysis of the factual findings in each of these decisions is beyond the scope of this article, a brief summary of the Court's findings in Podins and Kisluk is sufficient to provide a flavour of the complexity of this issue.

141 Although, as noted above, in Vitols the Court found that the applicant had failed to meet her burden to demonstrate that the applicable screening criteria would have excluded the respondent. 
Kisluk found that the respondent applied to enter Canada in December 1948 from the I.R.O. Resettlement Centre in Butzbach, Germany. On the basis of the testimony of former immigration officers, ${ }^{142}$ it was found that, in 1948, displaced persons seeking admission to Canada would first be processed by the I.R.O. and then screened by a three-person Canadian team. This team included an immigration officer, a medical officer, and a security officer; the RCMP security officer would first interview the applicant and then send the applicant to see the other two officers. ${ }^{143}$ Lutfy J. found that the security officer would have asked multiple questions and would have inquired about the employment history of the applicant since 1939. According to Lutfy J., this questioning would have sought to elicit information from the respondent regarding his assistance to the Germans as a railway guard and an auxiliary policeman. ${ }^{144} \mathrm{This}$, in combination with the finding that Kisluk would have been a collaborator under the applicable security screening criteria, resulted in a finding that the respondent had in fact gained entry to Canada and obtained Canadian citizenship by deception.

A very different finding was made in Podins. The respondent was found to have worked as a shopkeeper in the Valmiera Replacement prison $^{145}$ in Valmiera, Latvia, from 1941-1943. In 1945, he was taken prisoner of war by the British, discharged in 1946, and, in 1955, became a British citizen; the respondent applied to come to Canada from London in 1959. According to McKeown J., in 1959, British subjects, whether by birth or naturalization, were exempt from security screening. Further, applicants who were processed through London were not required to complete the "OS.8," an immigration application form which required an applicant to provide information about his or her residence and employment since 1939; such questions would have elicited information about wartime activities. According to McKeown J., although immigration officers had the discretion to refer otherwise exempt individuals for security screening, the existence of such discretion could not lead to the conclusion that there was a "consistent practice among immigration officers" to do so. ${ }^{146}$

\section{Duty of Candour}

An additional issue in the context of security screening, which is legal rather than factual in nature, is whether, on their application to immigrate to Canada and later applications for citizenship, potential immigrants post-WWII had a duty of candour. In other words, even if the respondents in these cases were not asked specific questions about their wartime activities, was there a legal duty to volunteer this information? The existence of such a duty would make the case of the Minister considerably easier to prove.

\footnotetext{
142 Immigration officers were not RCMP security officers.

143 Kisluk, supra note 4 at paras. 109, 120, 188.

144 Ibid. at paras. 196-97.

i4s McKeown J. found that, contrary to the allegation in the Notice of Revocation, the Valmiera Replacement prison was not a concentration camp but "a prison under the control of the German occupiers in the years in question." Podins, supra note 7 at para. 161. 
Section 33(2) of the Immigration Act, $1927,{ }^{147}$ in force in the years immediately after WWII, provided that:

2. Every passenger or other person seeking to enter or land in Canada shall answer truly all questions put to him by any officer when examined under the authority of this Act; and any person not truly answering such questions shall be guilty of an offence and liable on conviction of a fine..... ${ }^{148}$

Further, under s. 10 of the Citizenship Act, $1946,^{149}$ in order to obtain citizenship, an individual was required, inter alia, to have been "lawfully admitted to Canada for permanent residence," have resided in Canada for the requisite period, ${ }^{150}$ and be of "good character."

The law is unclear on the duty these provisions imposed upon the prospective immigrant and citizen, however. The first revocation decision involving WWII collaboration, Luitjens, held that under the Citizenship Act there is no duty to disclose information absent relevant questions. ${ }^{151}$ In contrast, Bogutin, and both Katriuk and Kisluk decided in 1999, held the opposite, citing the decision of the Supreme Court of Canada in Minister of Manpower and Immigration v. Brooks. ${ }^{152}$

In Brooks, the provision under interpretation was s. 19(1)(e)(viii) of the Immigration Act, 1952 which read:

19.(1) Where he has knowledge thereof, the clerk or secretary of a municipality in Canada in which a person hereinafter described resides or may be, an immigration officer or a constable or other peace officer shall send a written report to the Director, with full particulars, concerning...

(e) any person, other than a Canadian citizen or a person with Canadian domicile, who...

(viii) came into Canada or remains therein with a false or improperly issued passport, visa, medical certificate or other document pertaining to his admission or by reason of any false or misleading

147 R.S. 1927, c. 93, s. 33, para. 2 [hereinafter Immigration Act, 1927] [emphasis added].

148 There was also s. 33, para. 7 of this Act which provided that:

7. Any person who enters Canada except at a port of entry, or who at a port of entry eludes examination by an officer, or Board of Inquiry, or who enters Canada by force or misrepresentation or stealth or otherwise contrary 10 any provision of this Act, or who escapes from custody of an officer or from an immigration station when detained for any cause under this Act, shall be guilty of an offense under this Act... [emphasis added].

This provision would appear, however, to apply to individuals who did not properly enter Canada through a port of entry.

S.C. 1946, c. 15, s. 10 [hereinafter Citizenship Act, 1946].

The general residence requirement was that a person have resided continuously in Canada for one year immediately preceding the application for citizenship and resided, not necessarily continuously, for not less than four years in the six years preceding the application.

Luitjens, supra note 8 at 288. Although the case was decided in favour of the Minister on other grounds, Collier $\mathbf{J}$. held that absent questions, Luitjens had not been required to disclose to citizenship authorities his Nazi activities in the Netherlands nor deception about his escape to Germany and then to Paraguay.

[1974] S.C.R. 850 [hereinafter Brooks]. 
information, force, stealth or other fraudulant or improper means, whether exercised or given by himself or by any other person. ${ }^{153}$

Brooks had failed to disclose that he was subject to a Philippines deportation order and at issue was whether, in the absence of a specific question, he had a duty to disclose this fact. Laskin J. found that he did and wrote for the Court as follows:

I would repudiate any contention or conclusion that materiality under $s .19(1)(e)($ viii) requires that the untruth or the misleading information in an answer or answers be such as to have concealed an independent ground of deportation. The untruth or misleading information may fall short of this and yet have been an inducing factor in admission. Evidence, as was given in the present case, that certain incorrect answers would have had no influence in the admission of a person is, of course, relevant to materiality. But also relevant is whether the untruths or the misleading answers had the effect of foreclosing or averting further inquiries, even if those inquiries might not have turned up any independent ground of deportation. ${ }^{154}$

In the context of the interpretation of similar provisions of the Immigration Act, it has been held that the duty of candour owed by an applicant depends on the materiality of the information withheld; a fact will be material if a failure to disclose it would have the effect of "foreclosing or averting further inquiries." disclose the existence of three children is material in that its effect is to prevent inquiries into the status and circumstances of these children, which could be relevant to the determination of the application for permanent residence. ${ }^{156}$

The reasoning in Brooks was applied in both Katriuk and Kisluk. ${ }^{157}$ According to Nadon J. in Katriuk, "even if the department's investigation had not led to the rejection of the respondent, the circumstances concealed by the respondent [his wartime activities] are nonetheless material."158 Nadon J. found it irrelevant whether, in the face of such information, an immigration officer may have nonetheless exercised his or her discretion to admit an individual who was in his or her view a collaborator. In Kisluk, Lutfy J. stated that according to the respondent's version of events, ${ }^{159}$ he was only asked in regard to his wartime activities whether he had been a member of the SS. Lutfy J. found as fact that the Schutzmannschaften (auxiliary police) was a part of the

Immigration Act, R.S.C. 1952, c. 325 [hereinafter Immigration Act, 1952] [emphasis added]. This $A c t$ was proclaimed in force 15 September 1953.

ist Brooks, supra note 152 at 873 [emphasis added].

iss Ibid. See also Mohammed v. Canada (Minister of Citizenship and Immigration), [1997] 3 F.C. 299 (T.D.) [hereinafter Mohammed]; Hilario v. Minister of Manpower and Immigration (1977), [1978] I F.C. 697 (C.A.); Minister of Employment and Immigration v. Gudino (1981), [1982] 2 F.C. 40 (C.A.); Juayong v. Minister of Employment and Immigration (1988), 99 N.R. 78 (F.C.A.); Medel v. Canada (Minister of Employment and Immigration), [1990] 2 F.C. 345 (C.A.); and Chan v. Canada (Minister of Citizenship and Immigration) (1995), 102 F.T.R. 154 (T.D.) appear to hold that an "innocent" misrepresentation would not form the basis for such a finding. In Mohammed, however, Mackay J. rejected the argument that a misrepresentation must be made knowingly.

15. Okwe v. Canada (Minister of Employment and Immigration) (1991), 136 N.R. 261 at 264 (F.C.A.).

157 See also Bogutin, supra note 20 at 32-33 which also relies on the reasoning of the Supreme Court in Brooks to find the existence of a duty of candour.

158 Katriuk, supra note 6 at para. 146.

159 The respondent's version was not accepted as credible by the Court. 
SS and that, even if the respondent did not know this, the question with respect to the SS was material. As such, a duty of candour existed and the respondent's failure to volunteer that he served with the auxiliary police was deceptive. ${ }^{160}$

The issue of the duty of candour is a difficult one ${ }^{161}$ and, in the context of conflicting jurisprudence on the extent of this duty, this issue will certainly be raised again. There are several aspects of this question worthy of consideration. First, it is notable that while the provision under consideration in Brooks referred to a person entering Canada "by reason of any false or misleading information, force, stealth or other fraudulant or improper means," the Immigration Act, 1927, in force until $1953,{ }^{162}$ required that a person "answer truthfully" all questions. While the decisions to date have not focused on this difference in wording, ${ }^{163}$ it is relevant that Laskin J. stated in Brooks:

[I]f the materiality of matters on which no questions are asked is cognizable under s. 19(1)(e)(viii), it would be under the words "other fraudulant or improper means". They are broad enough to embrace non-disclosure of facts which would be material to admission or non-admission if known. ${ }^{\text {tht }}$

Given the absence of such wording in the Immigration Act, 1927, this may be a relevant factor for future judicial consideration.

Second, even applying the reasoning in Brooks, it is likely that the courts will recognize some limitations on the scope of the duty of candour in the context of WWII citizenship revocation cases. The law does not require that an individual volunteer information about every aspect of their past upon application to enter Canada. It would appear that the duty of candour or disclosure must be related to the information

Kisluk, supra note 4 at n. 170.

Fortunately, I am in good company in this respect. The Commission of Inquiry on War Criminals noted in 1986 that:

Faced with such conflicting views by a public servant, lawyers and academics, law officers of the Crown and the highest courts [on the duty of candour], the Commission finds itself in the invidious position of having to make a choice: so it will.

On the one hand, the applicant can be held to no duty beyond that imposed by the relevant statute: submit to questions, then answer truthfully. However, that process must take into consideration a particular ground for denaturalization: concealment of material circumstances. There, a duty of candour emerges: no information may be withheld, even absent any relevant question, which is material to the disposition of the application.

This conclusion is consonant with the burden which ss. 8(1) of the Immigration Act, 1976 imposes on the applicant:

8. (1) Where a person seeks to come into Canada, the burden of proving that he has a right to come into Canada or that his admission would not be contrary to this Act or the regulations rests on him.

Canada, Commission of Inquiry on War Criminals, Report, Part 1: Public (Ottawa: Minister of Supply and Services, 30 December 1986) at 195-96 (Commissioner Honourable Jules Deschênes). This was the $A c t$ in force at the time many of the individuals alleged to have collaborated with the Germans would have applied to enter Canada.

In Katriuk and Bogutin it was held that the wording in s. 33, para. 2, of the Immigration Act, 1927 , supra note 147, and the wording of the provision under analysis in Brooks was "similar." See Katriuk, supra note 6 at para. 147 and Bogutin, supra note 20 at para. 32.

Brooks, supra note 152 at 870 [emphasis added]. 
requested of individuals by immigration officials; while such a duty should not be narrowly construed to arise only in relation to specific questions, it must be clear from the nature or subject matter of the questioning what type of information is sought by immigration officials. Alternatively, it must be the case that the information which was not disclosed, while not the subject of a relevant question, was generally known by potential immigrants to be material information.

It is relevant to note that, in Kisluk and Katriuk, the courts concluded both that the applicable security screening criteria would have prohibited the entry of the respondents and that the respondents would have been asked questions eliciting information about wartime activities. It appears that, where a court finds the existence of applicable security screening criteria but the absence of questions which would jog information $^{165}$ about alleged wartime activities, the scope of the duty of candour becomes more questionable. It is also relevant to note that in the post-WWII context, it was apparently the intention of Cabinet that the applicable security screening criteria be kept secret; public servants were specifically advised through Cabinet Directive No. 14 that applicants, their relatives, or sponsors were not to be informed of the reason for an individual's rejection if it was based on security grounds. ${ }^{166}$ When the grounds of rejection were intentionally kept secret from prospective applicants, further questions can be raised about the scope of the duty of candour regarding information clearly material from the perspective of immigration officials.

Finally, although it has been held that the substantive rights of a respondent in a revocation proceeding are governed by the Citizenship Act under which they accrued $^{167}$ and that S. 21(b) of the Citizenship Act, 1946 did not require a "knowing" concealment of material circumstances ${ }^{168}$ to justify citizenship revocation, it is the case that such a knowledge requirement exists under the current $A c t$. The wording of ss. 10(1) and 10(2) of the current Act thus provide a further argument that a respondent must have had notice in some form that the non-volunteered information was relevant.

\section{Legal Authority FOR SECURITY SCREENING}

The final issue, which conceptually is a primary question in respect of citizenship revocation for alleged WWII collaboration, is whether, in the immediate post-WWII period, there was legal authority for the security screening and rejection of collaborators. To the extent that there was no such legal authority, there is some question as to whether individuals could be denied admission to Canada on the basis of collaborationist activities. ${ }^{169}$ While the courts to date have found that after 1950 there was legal authority for security screening, the decisions of the court in Dueck and

As noted above, by this I do not mean that specific questions must be asked about the alleged wartime activities but rather questions of a nature indicating to the individual that the type of activity in which they have engaged would be of interest to immigration officials. See Katriuk, supra note 6 at para. 93 for the text of Cabinet Directive No. 14.

See Luitjens No. I, supra note 30 at 132-33 and Bogutin, supra note 20 at 30 . In contrast, the procedural rights are those in force when the legal proceedings were commenced.

This would appear to directly address a situation where information is withheld as opposed to false information being volunteered.

For a statement to this effect, see Dueck, supra note 3 at 69. 
Kisluk differ on whether there was such authority in 1948. The Court in Dueck found that there was no such authority, while the Court in Kisluk found the opposite.

The first provision of relevance to this question is s. 3 of the Immigration Act, 1927, which, in 1948, provided that immigrants, passengers, or other persons ${ }^{170}$ listed in the "prohibited classes" were not permitted to land or enter Canada. This list of prohibited classes included: persons convicted of or who admitted committing "any crime involving moral turpitude"; $; 17$ advocates of force or violence against organized government; ${ }^{172}$ members of organizations opposed to organized government or advocates of the unlawful assault or killing of officers of organized government; ${ }^{173}$ past or present enemy aliens or persons interned after November 11, 1918; ${ }^{174}$ persons guilty of espionage against His Majesty or His Majesty's allies; ${ }^{175}$ persons found guilty of treason, assisting His Majesty's enemies in time of war or a similar offense against allies; ${ }^{176}$ or anyone who, between August 1, 1914, and August 1, 1924, had been deported from the dominions or an allied country on account of either treason or conspiring against His Majesty or His Majesty's allies. ${ }^{177}$ In addition, there was a catch all provision prohibiting the entry of:

(i) Persons who do not fulfil, meet or comply with the conditions and requirements of any regulations which for the time being are in force and applicable to such persons under this Act. ${ }^{\text {in }}$

Further, s. 38 of the Immigration Act, 1927 provided that:

The Governor-in-Council may, by proclamation or order whenever he deems it necessary or expedient,

(c) prohibit or limit in number for a stated period or permanently the landing in Canada, or the landing at any specified port or ports of entry in Canada, of immigrants belonging to any nationality or race or of immigrants of any specified class or occupation, by reason of any economic, industrial or other condition temporality existing in Canada or because such immigrants are deemed unsuitable having regard to the climatic, industrial, social, educational, labour or other conditions or requirements of Canada or because such immigrants are deemed undesirable owing to their peculiar customs, habits, modes of life and methods of holding property, and because of their probable inability to become readily assimilated or to assume the duties and responsibilities of Canadian citizenship within a reasonable time after their entry. ${ }^{179}$

Several orders-in-council were passed under the authority of s. 38(c).

Immigration Act, 1927, supra note 147. This list was not applicable to Canadian citizens or those with Canadian domicile.

lbid. at s. 3(d).

Ibid. at s. 3(n).

Ibid. at s. 3(o).

Ibid. at s. 3(p).

lbid. at s. 3(q).

Ibid. at s. 3(r).

Ibid. at s. 3(s).

lbid. at s. 3(i).

Ibid. at s. 38(c) [emphasis added]. 
Dueck and Kisluk differ in their interpretations of these provisions and, as a result, reach different conclusions on the existence of both statutory authority and Crown prerogative for security screening. The existence of Crown prerogative will be addressed first.

\section{Crown prerogative has been defined as:}

the powers and privileges accorded by the common law to the Crown. Dicey described it as "the residue of discretionary or arbitrary authority, which at any given time is left in the hands of the Crown". The prerogative is a branch of the common law, because it is the decisions of the courts which have determined its existence and extent. ${ }^{101}$

As Crown prerogative is a common law power, to the extent legislation covers an area previously covered only by Crown prerogative, the Crown must comply with the statute. $^{181}$ Since s. 17 of the Interpretation $A c t^{182}$ provides that no enactment is binding on Her Majesty or affects Her Majesty's rights or prerogatives, except as "mentioned or referred to in the enactment,"183 at issue in Dueck and Kisluk was whether the provisions of the Immigration Act, 1927, were so comprehensive as to supplant the Crown's prerogative with respect to the security screening of prospective immigrants.

In Dueck, it was held that the Immigration Act, 1927, covered the whole area. According to Noël J., this statute, and particularly the wording of s. 38(c), gave the Minister of Mines and Resources ${ }^{184}$ the authority to prohibit the entry of immigrants on any ground, including collaboration with the enemy. In contrast, although also finding that the orders-in-council in effect in 1948 provided sufficient authority for the security screening of potential immigrants, in Kisluk, Lutfy J. pointed to three factors which made it questionable whether the Immigration Act, 1927, had fully displaced the Crown prerogative. First, Lutfy J. noted that when ss. 3 and 38 were first enacted in the Immigration Act of 1910, Canada was not yet a fully sovereign nation and its national security resources were meagre; at this time it is unlikely that Parliament

P.W. Hogg, Constitutional Law of Canada, 4th ed. (Toronto: Carswell, 1997) at 15 [citations omitted].

181 Ibid. at 17. See also P. Lordon, Crown Law (Toronto: Butterworths, 1991) at 65-67 and Desjardins v. Bouchard, [1983] 2 F.C. 641 (C.A.).

1 R2 R.S.C. 1985 , c. $1-21$, s. 17.

183 As noted in Kisluk, supra note 4 at para. 155, the words "mentioned or referred to" in s. 17 of the Interpretation $\mathrm{ACl}$ have been given a broad interpretation by the Supreme Court in Alberta Government Telephones v. Canada (Canadian Radio-television and Telecommunications Commission), [1989] 2 S.C.R. 225. At 281, it is noted that:

It seems to me that the words "mentioned or referred to" in [s. 17] are capable of encompassing: (1) expressly binding words ("Her Majesty is bound"); (2) a clear intention to bind which, in Bombay terminology, "is manifest from the very terms of the statute", in other words, an intention revealed when provisions are read in the context of other textual provisions...; and, (3) an intention to bind where the purpose of the statute would be "wholly frustrated" if the government were not bound, or, in other words, if an absurdity (as opposed to simply an undesirable result) were produced. These three points should provide a guideline for when a statute has clearly conveyed an intention to bind the Crown. 
considered the security issues that emerged in the post-WWII period. Second, the wording of s. 38(c), which allowed the Governor-in-Council to prohibit the entry of individuals who did not meet the "other conditions or requirements of Canada," referred to a prohibition based on socio-economic factors rather than security concerns. Finally, the Immigration Act, 1927 did not provide a right to enter Canada for persons overseas and thus, even if an individual did not fall within a prohibited class, no such right existed. $^{185}$

In respect of statutory authority for security screening, Noël J. held in Dueck that, although s. 38(c) was broad enough to provide the Governor-in-Council authority to make regulations for security screening, this had not in fact been done. Noël J. noted that in the summer of 1948 , there were four relevant orders-in-council in place. The first, P.C. $4849,{ }^{186}$ provided in part that:

His Excellency in Council pursuant to the provisions of Section 38 of the Immigration Act, Chapter 93, R.S.C. 1927, is pleased to make the following Order and it is hereby made and established in substitution for the regulations hereby revoked:

\section{ORDER}

From and after the date hereof and until such time as otherwise ordered, the landing in Canada of immigrants of all classes and occupations, is prohibited, except as hereinafter provided:

The Immigration Officer-in-Charge may permit any immigrant who otherwise complies with the provisions of the Immigration Act to land in Canada, if it is shown to the satisfaction of such Officerin-Charge that such immigrant is:...

P.C. 4849 then listed the admissible classes. Second, and also made pursuant to s. 38 of the Immigration Act, 1927, was P.C. 4850, which prohibited the entry of enemy aliens unless they satisfied the Minister of Mines and Resources that they were opposed to the enemy government. ${ }^{187}$ The third order-in-council in effect was P.C. $4851,{ }^{188}$ which is also worth reproducing in part:

His Excellency in Council, on the same recommendation and pursuant to the provisions of section 37 of the Immigration Act, chapter 93, Revised Statutes of Canada 1927, is pleased to make the following regulation and it is hereby made and established in substitution for the regulations hereby revoked:

From and after the date hereof every person seeking to enter or land in Canada, shall be in possession of an unexpired passport issued by the country of which such person is a subject or citizen;

Kisluk, supra note 4 at paras. 159-63.

Prohibiting the landing in Canada of immigrants with certain exceptions, P.C. 1947-4849, SOR/47-920, C. Gaz. 1947.II.2338.

Prohibiting the entry into Canada of enemy aliens, P.C. 1947-4850, SOR/47-921, C. Gaz. 1947.II.2339. This Order-in-Council would most obviously apply to individuals of German nationality. It specifically provided that it did not apply to nationals of Finland, Hungary, Italy, and Romania.

Regulation respecting the production of passports by immigrants to Canada, P.C. 1947-4851, SOR/47-922, C. Gaz. 1947.11.2340. 
Provided: ...

2. That the passport of every alien sailing directly or indirectly from Europe shall carry the visa of a Canadian Immigration Officer stationed in Europe; ...

4. That a travel document establishing the identity of the holder may be accepted in lieu of a passport in the case of an immigrant who has been displaced from his country of origin as the result of the war and who is not in possession of a valid passport.

It is of note that P.C. 4851 was passed under the authority of s. 37 of the Immigration Act, 1927, which provided that the Governor-in-Council could make regulations requiring immigrants to possess a minimum amount of money and produce a passport issued within a prescribed time limit or "viséd in the manner required." 189 Finally, and importantly in the case of Dueck, was P.C. $2180,{ }^{190}$ the first of a series of orders-in-council providing for the admission of large numbers of displaced persons from Europe in the post-WWII years. It provided in part that:

[A]s a contribution towards the solution of this problem and notwithstanding anything to the contrary contained in Order in Council P.C. 695 dated the 21st of March, 1931, authority be granted for the immediate admission to Canada of five thousand individuals from the displaced persons camps in Europe;

That the Minister of Mines and Resources be directed to make provisions through the Immigration Branch and through the utilization of whatever assistance may be required and may be made available to him by the Minister of Labour, for the selection and transportation to Canada of the five thousand displaced persons aforesaid. ${ }^{191}$

According to the applicant Minister, it was the reference in P.C. 2180 to the "selection" of displaced persons that provided the authority for the security screening and rejection of potential immigrants. Noël J. rejected this argument on three grounds. First was the fact that security screening was "a measure of general application" and P.C. 2180 was directed only at displaced persons coming under its authority. ${ }^{192}$ Second, when the Governor-in-Council sought to exclude a specific class of individuals in 1948, it did so expressly. Finally, looking to Cabinet and other high level documents,

Immigration Act, 1927, supra note 147. The relevant part of this provision read:

Regulations made by the Governor-in-Council under this Act may provide, as a condition to permission to enter or land in Canada, that immigrants and any of the non-immigrant classes, except ... shall possess in their own right, money to a prescribed minimum amount which amount may vary according to the nationality, race, occupation or destination of such persons and otherwise according to the circumstances; and may also provide that all persons coming to Canada directly or indirectly from countries which issue passports shall produce such passports on demand of the immigration officer in charge before being allowed to enter or land in Canada, and may provide also that passports shall not be recognized unless issued within a time limited by regulations or unless viséd in the manner required.

P.C. 1947-2180. P.C. 1947-2856, P.C. 1947-3926, P.C. 1948-1628, and P.C. 1948-3721 progressively increased to 40,000 the number of displaced persons admissible to Canada from the 5000 originally entitled to land under P.C. 1947-2180.

P.C. 1947-2180 [emphasis added].

Dueck, supra note 3 at 63. 
Noël $\mathrm{J}$. found that although the question of legal authority for the security screening and vetting of immigrants had been at issue from this program's inception, it was never suggested that P.C. 2180 or any other order-in-council in 1948 created the authority for it. ${ }^{193}$ According to Noël J., it was not until the introduction in 1950 of P.C. $2856,{ }^{194}$ which essentially tracks the wording of s. 38(c) of the Immigration Act, 1927, that an attempt was made to provide the authority for security screening of potential immigrants.

In addressing the legal effect of the applicable orders-in-council, Lutfy J. noted that, in comparison with Dueck, "the applicant's submissions in [Kisluk] differed substantially. In particular, the applicant appears to have placed far greater reliance on P.C. 4849 in this case than in Dueck."195 Consistent with his analysis on the issue of Crown prerogative and his view that the words "other conditions or requirements" in s. 38(c) of the Immigration Act, 1927 did not provide the statutory authority for security screening, Lutfy J. held that the similar wording in P.C. 2856 did not provide the authority to prohibit the entry of undesirables into Canada. However, he found authority for security screening elsewhere. First, Lutfy J. pointed to a series of orders-in-council, of which P.C. 4849 was one, which created a total prohibition against the landing of all immigrants and which provided that the immigration officer "may permit" the admission of only certain other named classes. ${ }^{196}$ Second, he pointed to P.C. 4851 which required that the passport or travel document ${ }^{197}$ of every alien sailing from Europe have the visa of a Canadian immigration officer stationed in Europe. According to Lutfy J., there was no entitlement to a visa in 1948, and its issuance was discretionary. Information from a security officer that an individual who otherwise complied with the Immigration Act, 1927 was a security risk, would be a justifiable basis upon which an immigration officer could use his or her discretion, under either or both P.C. 4851 and P.C. 4849, to prohibit the entry of such an individual to Canada. This would be consistent with s. 3(i) of the Immigration Act, 1927, which made those not complying with the conditions or requirements of the regulations a prohibited class.

The difference in reasoning in Dueck and Kisluk is substantial, and, in the absence of a right of appeal from such a decision, we must wait to see which approach is preferred in future cases. ${ }^{198}$ This will not be an easy issue to resolve and there are

lbid. at 63-64.

Order re landing of immigrants in Canada. P.C. 1950-2856, SOR/50-232, C. Gaz. 1950.1I.765. This order-in-council gave the Immigration Officer-in-Charge the discretion to refuse the landing of a prospective immigrant unless it could be shown that the person:

4. (a) ... is a suitable immigrant having regard to the climatic, social, educational, industrial, labour, or other conditions or requirements of Canada; and

(b) is not undesirable owing to his peculiar customs, habits, modes of life, methods of holding property, or because of his probable inability to become readily adapted and integrated into the life of a Canadian community and to assume the duties of Canadian citizenship within a reasonable time after his entry.

Kisluk, supra note 4 at $n .147$.

P.C. 1931-695 was the first such order-in-council. P.C. 1949-2743, P.C. 1947-4849, and P.C. 19472856 progressively widened the classes of admissible immigrants.

The travel document applied in the case of a displaced person without a passport.

While the analysis in Dueck is cited with approval in Katriuk, this was in obiter and the issue of security screening was not fully explored in the course of these reasons. 
several aspects of it which will undoubtedly be the subject of further analysis. First, in respect of Crown prerogative, it is certainly arguable that Lutfy J. was correct in concluding that the wording of s. 38(c) permitted the Governor-in-Council to make regulations prohibiting the entry of classes of immigrants only based on socio-economic factors. The wording of this paragraph may not in fact provide that individuals should be denied entry to Canada on the basis that they constitute some type of risk to Canada. Rather, this provision may in fact have been directed towards ensuring that immigrants fit within Canada's socio-economic needs and would assimilate easily into Canadian society. There is thus some question whether s. 38(c) provided authority for security screening and ousted the Crown's prerogative in this respect.

Having said this, there is a strong argument that s. 3 of the Immigration Act, 1927 purports to cover the subject matter at issue, the non-admission to Canada of persons thought to be a security risk. Section 3 deals with a number of national security issues and, as noted above, prohibits the entry of persons who believe in the overthrow of the Government of Canada and persons guilty of espionage. In respect of collaborators, s. 3(d) prohibits the entry into Canada of:

(d) Persons who have been convicted of, or admit having committed, any crime involving moral turpitude. ${ }^{199}$

Section 3(r) prohibits the entry of:

(r) Persons who have been found guilty of high treason or treason or of conspiring against His Majesty, or of assisting His Majesty's enemies in time of war, or of any similar offence against any of His Majesty's allies. ${ }^{2(x)}$

In light of these provisions, it is arguable that Parliament did in fact address issues of national security and the undesirability of collaborators in the Immigration Act, 1927; it chose, however, only to prohibit the entry of those who had in fact been convicted for such activity and those who had been convicted of or admitted to crimes involving moral turpitude. On this analysis, the Crown prerogative with respect to security screening would be supplanted by necessary implication, and the Crown would thus be required to comply with the terms of the statute. While ss. 3(d) and 3(r) would clearly provide immigration officials with the authority to question potential immigrants to determine whether they fell within the classes prohibited therein, these provisions do not appear to provide authority for the rejection of collaborators on grounds other than these.

This analysis rests on a broad interpretation of the purpose of s. 3 of the Immigration Act, 1927, as attempting to address security concerns generally. It is notable, however, that this section enumerates a number of non-security related classes, such as the diseased or those with disabilities. It is thus arguable that s. 3 was not intended to cover all security risks but merely to enumerate some of them. To the extent that such an 
analysis is accepted, it is arguable that a Crown prerogative subsisted and provided the legal authority for security screening on the basis of security concerns unenumerated in s. 3.

In respect of the authority provided by legislation and the applicable orders-incouncil, the decision in Kisluk identifies an interesting basis upon which to ground legal authority for security screening and vetting, the discretion given to immigration officers and the absence of a right of entry to Canada. When this issue is again adjudicated, there are several further issues that may be considered. First, although P.C. 4849 provided that an immigration officer "may permit" the landing of individuals in Canada, s. 33(3) of the Immigration Act, 1927, stated that:

Every passenger or other person so examined shall be immediately landed unless the examining officer has reason to believe that the landing of such passenger or other person would be contrary to any provision of this Act. $^{201}$

It is thus arguable that P.C. 4849 purports to give the immigration officer a broader grant of discretion than authorized by the mandatory wording of s. 33(3) of the Immigration Act, $1927 . .^{202}$ Second, P.C. 4849, according to its text, was made under the authority of s. 38 of the Immigration Act, 1927. If, however, it is the case that s. 38(3) does not provide authority for screening and rejection on security grounds, there is some question whether any discretion exercised by an immigration officer under its authority could be exercised on the basis of security concerns. Third, the requirement for a visa under P.C. 4851 was made pursuant to s. 37 of the Immigration Act, 1927. Section 37 allows the Governor-in-Council to provide inter alia that passports "be viséd in the manner required." It is unclear whether this requirement was merely procedural in nature, thus requiring a travel document to demonstrate that its holder had in fact seen a Canadian immigration officer, or whether it implies the existence of substantive grounds upon which the visa could be refused. However, for an immigration officer to deny admission on security grounds on the basis of the discretion under P.C. 4851, the latter must be the correct interpretation of s. 37 .

The proper interpretation to be given to ss. 3, 33(3), 37, and 38(c) of the Immigration Act, 1927, as well as the orders-in-council passed under this Act, has important implications for WWII citizenship revocation cases involving immigration, at least until the introduction of changes to the law in $1953 .{ }^{203}$ Apart from the issue

201 Immigration Act, 1927, supra note 147 at s. 33(3) [emphasis added].

202 In Kisluk, supra note 4 at n. 140, Lutfy J. notes that "[t]he parties did not address, nor have I considered in any definitive way, whether subsection 33(3) of the Act provided a 'right to enter' for persons who satisfied an examining officer at a port of entry in Canada."

For example, The Immigration Act, 1952, supra note 153 at s. 61 provided that:

The Governor-in-Council may make regulations for carrying into effect the purposes and provisions of this Act and, without restricting the generality of the foregoing, may make regulations respecting ...

A list of the types of regulations allowed then followed. The wording of this provision is much broader than s. 38(c) under the Immigration Act, 1927, supra note 147. It should be noted, however, that the 1952 changes to the Immigration $A c l$ have not yet been considered in relation to the statutory authority for security screening. 
of authority for the outright rejection of individuals, as noted above, s. 33(2) provides that persons seeking to enter Canada must truthfully answer questions when put to them by an officer "when examined under the authority of this Act." ${ }^{204}$ If there was no authority under the Immigration Act, 1927 for security screening, there is some doubt of the effect of any misrepresentation or concealment of information in relation to questions of a security screening nature.

\section{CONCLUSION}

On July 21,1998 , the Federal Government announced that it would allocate $\$ 46.8$ million over the following three years to pursue its War Crimes Program. The Department of Justice received $\$ 16.5$ million of this funding to pursue WWII cases as well as modern-day war crimes cases on behalf of the Department of Citizenship and Immigration. ${ }^{205}$ Given this commitment, it is unlikely that citizenship revocation proceedings for alleged war crimes or collaboration will disappear from the docket of the Federal Court.

The revocation cases to date have laid the foundation for such future proceedings. While this article has demonstrated that there are many issues yet to be resolved in this area, particularly with respect to immigration and citizenship law in the post-WWII period, the recent jurisprudence has clarified the basic procedural framework within which citizenship revocation cases will go forward; the principles established in this area will apply to revocation proceedings for war crimes, collaboration, or for any alleged deception. While from an evidentiary perspective modern war crimes cases will be of a different nature than WWII cases in that the courts will likely have before them much better evidence, ${ }^{206}$ an understanding of the factual issues in the WWII revocation cases is nonetheless of assistance in this context. First, these cases illustrate the basic factual issues to be resolved in any such proceeding. Second, and perhaps most importantly from an evidentiary perspective, they illustrate in a dramatic way the advantage of proceeding with a case soon after the events in question have transpired. It is clear that the Government has a strong interest in proceeding quickly and systematically to attempt to exclude from Canada those who allegedly lied about their involvement in war crimes and crimes against humanity in order to gain entry to this country.

Immigration Act, 1927, ibid. at s. 33(2).

1998-1999 Annual Report, supra note 1 at 4.

This better evidence will partly be in the form of testimony from witnesses to the alleged collaboration or war crimes, testimony of the officials who interviewed the individual and investigated his or her past, and documentation regarding the representations made by the respondent. 